Check for updates

Cite this: RSC Adv., 2019, 9, 7854

\title{
Electro-membrane processes for organic acid recovery
}

\author{
L. Handojo, ${ }^{a}$ A. K. Wardani, ${ }^{a}$ D. Regina, ${ }^{a}$ C. Bella, ${ }^{a}$ M. T. A. P. Kresnowati ${ }^{a}$ \\ and I. G. Wenten (D)*ab
}

With an increase in the organic acid requirement, the production of organic acids has been increased over the years. To achieve cost-effective production of organic acids, efficient recovery processes are needed. Electro-membrane processes, including electrodialysis (ED), electrometathesis (EMT), electro-ion substitution (EIS), electro-electrodialysis (EED), electrodialysis with bipolar membrane (EDBM), and electrodeionization (EDI), are promising technologies for the recovery of organic acids. In the electromembrane processes, organic acids are separated from water and other impurities based on the electromigration of ions through ion-exchange membranes. These processes can recover various types of organic acids from the fermentation broth with high recovery yield and low energy consumption. In addition, the integration of fermentation and the electro-membrane process can improve the acid recovery with lower byproduct concentration and energy consumption.

Received 8th November 2018 Accepted 19th February 2019

DOI: 10.1039/c8ra09227c

rsc.li/rsc-advances polyester resins, dyestuffs, and pharmaceuticals; ${ }^{5}$ citric acid is widely used as a flavoring agent for foods and beverages as well as a cleaning and polishing agent, ${ }^{6-8}$ and formic acid is mainly used in the textile and paper industries., ${ }^{\mathbf{9}, 10}$

In general, there are two routes for the production of organic acids: chemical synthesis and carbohydrate fermentation. The chemical synthetic route is limited by its production capacity because it is associated with the byproduct of another process ${ }^{\mathbf{1 1}}$ and has high manufacturing costs; moreover, carbohydrate fermentation can utilize various raw materials and produce organic acids with a higher degree of safety; thus, it has mainly been chosen to produce organic acids in the recent years. ${ }^{\mathbf{1 2}} \mathrm{A}$ wide variety of renewable resources, such as silage, grains, syrups, molasses, and cheese whey, can be used as raw materials in carbohydrate fermentation. However, the fermentation

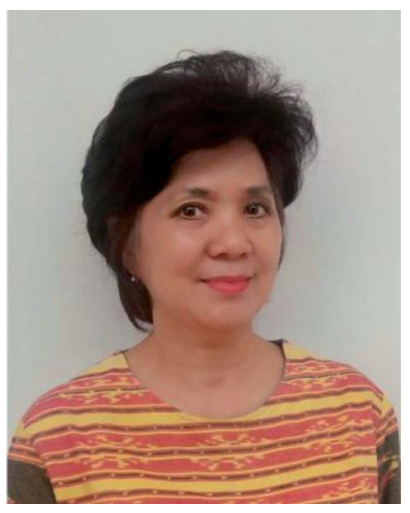

Lienda Handojo received her Bachelor's Degree in Chemical Engineering from the Institut Teknologi Bandung (ITB), Indonesia, her Master's Degree in Food Process Engineering from Asian Institute of Technology, Thailand, and her Doctoral Degree in Technical Chemistry from the University Hannover, Germany. She is currently an Associate Professor in Bioprocess Technology, ITB. Her

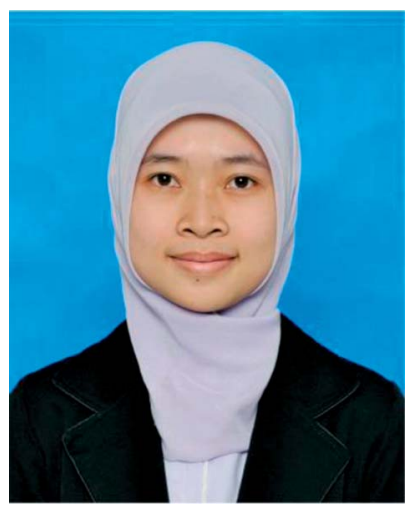

Anita Kusuma Wardani graduated with Bachelor's and Master's degrees in Chemical Engineering from Institut Teknologi Bandung (ITB), Indonesia in 2013 and 2016, respectively. She is currently a doctoral student in Chemical Engineering, ITB, under the supervision of Prof. I. Gede Wenten. Her research interests include the preparation, modification, and application of membranes.

research focuses on separation, food and bioproduct processing. 
broth obtained from these resources usually consists of various ingredients, and thus, its separation and purification are necessary to achieve high purity of the organic acids.

About $50-70 \%$ of the cost of the production of organic acid is generated by the recovery of the fermentation product. ${ }^{\mathbf{1 3 , 1 4}}$ Therefore, various technologies, such as precipitation, extraction, adsorption, ion-exchange system, membrane, etc. ${ }^{15-23}$ have been developed for the efficient recovery of organic acids. However, some of these conventional technologies, especially extraction, adsorption, and ion-exchange, require further concentration steps, produce dangerous waste, require hazardous solvents, and consume high energy. ${ }^{12}$ Therefore, the recovery of organic acids has been shifted from conventional technologies to electro-membrane processes including electrodialysis (ED), electrometathesis (EMT), electro-ion substitution (EIS), electro-electrodialysis (EED), electrodialysis with bipolar membranes (EDBM), and electrodeionization (EDI). The electro-membrane process separates organic acids from water and other impurities based on the electro-migration of ions through ion-exchange membranes. Thus, it can provide high quality product in a short time without salt introduction or discharge. ${ }^{3}$

Fig. 1 shows the number of publications on the recovery of organic acids since 1980. It can be seen that the number of publications on the recovery of organic acids has increased over years, with the highest number of publications in 2010. Based on technology, the publications on the recovery of organic acids via extraction was dominant with up to $51 \%$. However, since 2000 , there has been an increase in the number of publications on the recovery of organic acids via electro-membrane processes due to their ability to recover organic acids with high yield and without the requirement of solvent addition. In the earlier studies, ED was the only electro-membrane process applied for organic acid recovery. Compared to conventional processes, ED requires lower energy consumption and eliminates the use of solvent. However, the purity of the acid product from the ED process is relatively low. Therefore, many researchers have tried to develop the ED process via stack modification (i.e. EMT, EIS, and EED), membrane modification (i.e. EDBM), resin addition (i.e. EDI), and integration with other processes.

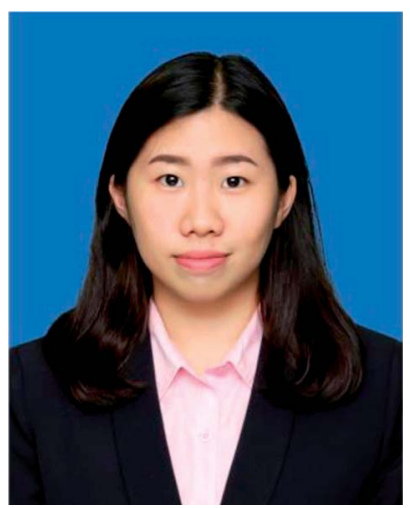

Devina Regina received a Bachelor's Degree in Chemical Engineering from Institut Teknologi Bandung, Indonesia in 2018. Her Bachelor's research was focused on the combination of ultrafiltration and electrodeionization membranes for the separation of xylitol from empty palm fruit bunch fermentation broth under the supervision of Prof. I. Gede Wenten.

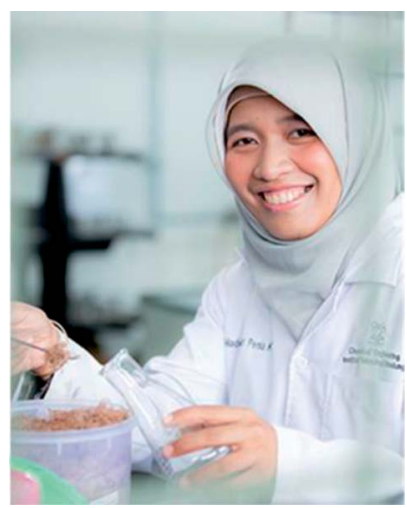

M. T. A. P. Kresnowati received her Bachelor's Degree in Chemical Engineering from the Institut Teknologi Bandung (ITB), Indonesia, her Master's Degree in (Bio)chemical Engineering from TU Delft, The Netherlands, and her Doctoral Degree in Bioprocess Technology from $\mathrm{TU}$ Delft. She is currently an Associate Professor in Bioprocess Technology, ITB. Her research interests include modeling of biosystems, fermentation processes, food processing, metabolomics, and membrane based process for fermentation products.

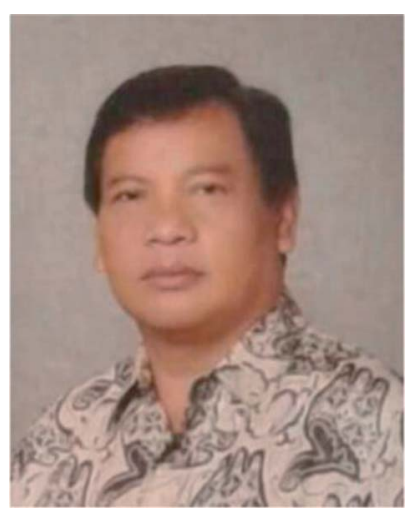

I. Gede Wenten received a Bachelor's Degree in Chemical Engineering from the Institut Teknologi Bandung (ITB), Indonesia, and Master's and Doctoral degrees from Technical University of Denmark (DTU), Denmark. He is currently a Professor of Chemical Engineering and a member of the Research Center for Nanosciences and Nanotechnology, ITB. He has significant experience in membrane technology both at the industrial and academic levels, with a career spanning over more than 20 years. His research interests include membrane preparation, membrane applications, and membrane fouling and mitigation. 


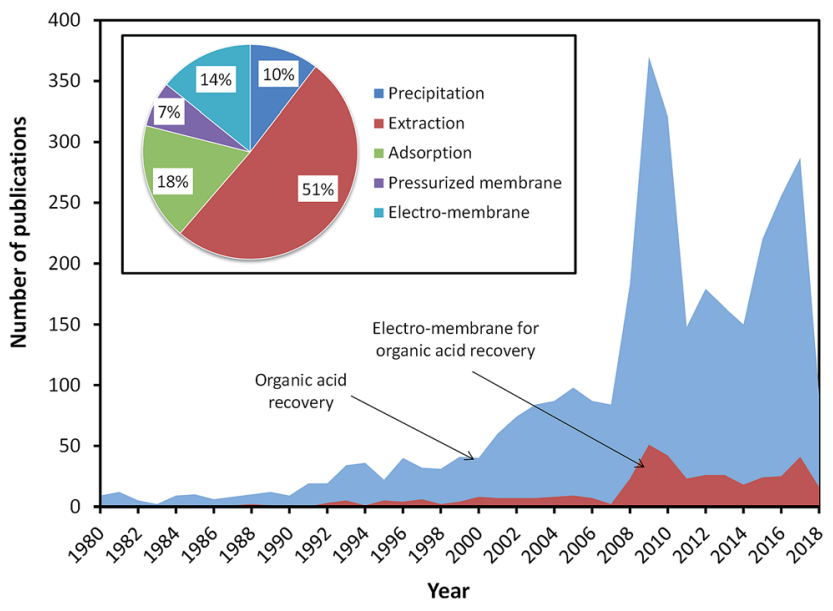

Fig. 1 The number of reported studies related to the search term organic acid recovery, as indexed by Scopus (TITTLE-ABS-KEY (terms); September 2018).

A review on the recovery of organic acids via electromembrane processes was published by Huang et al. in 2007.12 However, their review mainly focused on the ED configuration and its economic evaluation. Thus, for a better understanding of this process, we aim to provide a more comprehensive review of the recovery of organic acids using electro-membrane processes. The conventional processes for the recovery of organic acids are summarized to give a better overview on the state of the art of organic acid recovery. Meanwhile, the discussion on electro-membrane processes includes not only their configuration, but also their performances and design development on the recovery of various organic acids. In addition, the issues with electro-membrane processes and their possible solutions are discussed.

\section{Conventional processes for organic acid recovery}

Separation and purification of fermentation broth are the primary determinants for the cost-effective production of organic acids. Calcium precipitation using $\mathrm{Ca}(\mathrm{OH})_{2}$ or $\mathrm{CaO}$ is one of the most used methods to recover organic acids from fermentation broth. This method has been used for recovery of citric acid, ${ }^{25,26}$ lactic acid, ${ }^{27}$ and succinic acid.,28,29 Calcium precipitation offers the advantage of being directly performed on existing equipment, technology and infrastructure, and thus it has very low technological barriers and risks. ${ }^{24}$ Beside calcium precipitation, the recovery of succinic acids also has been conducted by ammonia precipitation. Succinic acid was recovered up to $93.3 \%$ using ammonia precipitation. ${ }^{30}$ Generally, precipitation produces a low amount of waste by-products since the used reagent can be recycled. However, this method requires high energy consumption and equipment erosion due to the low $\mathrm{pH}$ and high temperature in the reagent recycle process.

Liquid-liquid extraction has also been widely used for the recovery of organic acids. The liquid-liquid extraction system consists of two separate liquid phases, where the organic acid transfers from one phase to the other based on the solubility differences between the phases. ${ }^{31}$ In liquid-liquid extraction, the selection of an appropriate solvent is fundamental to obtain a high organic acid recovery rate. There are seven important criteria for solvent selection: (a) good distribution coefficient for organic acid uptake, (b) high separation capacity, (c) high selectivity, (d) easy product backwashing with water, (e) low tendency to emulsify, (f) low cost, and (g) non-toxic. ${ }^{32}$ Several organic solvents have been widely used, such as butyl alcohol, acetone and tributyl phosphate or with certain amines..$^{23,33-36}$ Among them, amine extraction is one of the most prospective methods for the separation of carboxylic or hydroxyl-carboxylic acid from aqueous solution. ${ }^{32,37,38}$

In several cases, the distribution of organic acids in the extraction phase seems to be unsatisfactory, and thus large quantities of extraction agent are required. Consequently, some researchers developed reactive extraction to solve this problem. The product from fermentation is firstly converted into a compound without carboxyl groups and then recovered by liquid-liquid extraction. ${ }^{24}$ This method has been used to recover succinic acid in several studies., ${ }^{5,39,40}$ The results showed that more than $95 \%$ succinic acid was recovered by reactive extraction. This method also has been applied for lactic acid, ${ }^{20,41-44}$ acetic acid, ${ }^{45-48}$ carboxylic acid, ${ }^{49,50}$ and propionic acid $^{\mathbf{2 1 , 5 1 , 5 2}}$ since these organic acids are poorly extractable by common organic solvents due to their hydrophilic nature.

The other alternative for the recovery of organic acids is the use of solid sorbents that are selective for organic acids. To obtain high recovery yield, the sorbent must have a high separation capacity for the acid and specificity for the product. ${ }^{\mathbf{2 4 , 4 1}}$ Alumina, activated carbon, silica, and zeolite molecular sieves are examples of sorbents widely used to recover organic acids from fermentation broth. To adsorb succinic acid, alumina ${ }^{53}$ and a high-silica zeolite $\left(\mathrm{SiO}_{2} / \mathrm{Al}_{2} \mathrm{O}_{3}=218\right)^{54}$ were chosen as sorbents. Meanwhile, for lactic acid recovery, adsorption by silicalite molecular sieves ${ }^{15}$ and activated carbon ${ }^{55}$ was used. In addition, activated carbon also has been utilized to recover acetic acid, butyric acid, fumaric acid, and propionic acid. ${ }^{\mathbf{1 8 , 1 9}}$ Several researchers also studied the use of ion exchange resins to adsorb organic acids. Various types of ion exchange resins such as alkaline-type anion exchange resins, ${ }^{56,57}$ weak base anion-exchange resins (Amberlite IRA-92, ${ }^{58}$ IRA-400, ${ }^{17,59-61}$ and IRA-900 (ref. 62)) and poly(4-vinylpyridine) (PVP) resins ${ }^{55,63-65}$ have been used. The studies showed that a weakly basic ion exchange resin was the best ion exchange resin for the purification of organic acids.

Membrane technologies have also proven for the advanced recovery of organic acids. Compared to other conventional technologies, pressure-driven membranes offer the advantages of process continuity and high selectivity. For small molecules such as organic acids and salts, nanofiltration (NF) membranes can be used to separate them efficiently. NF membranes consist of a dense, ultrathin skin layer on microporous polymeric supports, and mostly with charged groups on the membrane surface. ${ }^{66}$ The rejection mechanism in NF membranes is a combination of size sieving, solution-diffusion, and Donnan exclusion. ${ }^{67} \mathrm{NF}$ has been used for the recovery of lactic acid by 
several researchers. ${ }^{68-71}$ These studies showed that NF was able to recover highly purified lactic acid by removing $85 \%$ of mineral ions such as $\mathrm{Na}^{+}, \mathrm{K}^{+}, \mathrm{Mg}^{2+}$, and $\mathrm{Ca}^{2+}$ and $90 \%$ of residual carbohydrates. Several researchers also tried to combine NF with other processes such as microfiltration and ultrafiltration to improve the recovery efficiency. ${ }^{72-75}$ In addition, membrane distillation (MD) has also been studied to recover organic acids. The organic acid is separated from impurities by heating and evaporating the liquid and allowing the vapor to pass through a microporous hydrophobic membrane. Then the vapors are allowed to condense into liquid by cooling on the other side of the membranes. ${ }^{76}$ Ban et al. ${ }^{77}$ used this method to recover various types of organic acids, including glycolic acid, glyoxylic acid lactic acid, pyruvic acid, malonic acid, and glutaric acid. Their results showed that the rejection rate for all the abovementioned organic acids except pyruvic acid was above $97.0 \%$. Generally, MD is able to recover organic acids with a high recovery rate; however, its thermal energy efficiency is very low.

Table 1 shows the recovery yield of organic acids using various conventional technologies. It can be seen that most of them were successfully utilized to recover organic acids with recovery yields greater than $60 \%$. However, each technology has advantages and disadvantages, as summarized in Table 2 . Calcium precipitation offers the advantage of the ability to be directly used on existing equipment, technology, and infrastructure, and thus has very low technological barriers and risks. However, it has low selectivity and produces $\mathrm{CaSO}_{4}$ sludge. Liquid-liquid extraction offers some advantages, such as high purity product and low energy consumption, but the use of hazardous solvents leads to environmental problems. Moreover, adsorption using solid sorbents or ion exchange resins is a reliable technology, but it requires large amounts of chemicals for the regeneration of the ion exchange resins and adjustment of the feed $\mathrm{pH}$ to increase the sorption efficiency. Meanwhile, pressure-driven membranes have several advantages, such as process continuity and easy scale-up, compared to conventional technologies; however fouling is still the main limitation in membrane separation processes.

\section{Electro-membrane processes for organic acid recovery}

The improvement of technologies for organic acids recovery is very important since it is associated with fermentation process effectiveness and production costs. The conventional technologies generally need further concentration steps, produce dangerous waste, require hazardous solvents, and consume high energy. To solve those problems, organic acid recovery has shifted to electro-membrane processes. In electro-membrane processes, organic acids are separated from water and other impurities based on the electro-migration of ions through ionexchange membranes. These processes are able to recover various types of organic acids from fermentation broth with high purity and yield without requiring the use of solvent.

\section{Electrodialysis (ED)}

One of the promising technologies to obtain high purity organic acids without the requirement of any solvent is electrodialysis or ED. ED is an electrochemical separation process with the driving force of electrical potential difference to separate ionic species through ion exchange membranes. It has been applied for the production of table salt, organic acid recovery, heavy metal recovery, and sugar demineralization. ${ }^{98-101}$ ED mainly consists of three compartments, including diluate, concentrate, and electrode compartments. The compartments are separated

Table 1 Recovery yields of organic acids using conventional technologies

\begin{tabular}{|c|c|c|c|}
\hline Acid & Method & Recovery yield (\%) & Ref. \\
\hline \multirow[t]{3}{*}{ Acetic acid } & Extraction & $66-97$ & $35,45,46,48$ and 78 \\
\hline & Adsorption & 94 & 79 \\
\hline & Pressure-driven membrane & 88 & 80 \\
\hline Citric acid & Extraction & 90 & 37 \\
\hline Formic acid & Extraction & 87 & 81 \\
\hline \multirow[t]{2}{*}{ Fumaric acid } & Extraction & 70.7 & 22 \\
\hline & Adsorption & $85-93$ & 19 and 62 \\
\hline \multirow[t]{4}{*}{ Lactic acid } & Extraction & $37-97$ & $20,23,31,33,43$ and $82-84$ \\
\hline & Adsorption & $74-95$ & $15,17,65$ and 85 \\
\hline & Precipitation & 92 & 27 \\
\hline & Pressure-driven membrane & $60-100$ & 74,75 and 80 \\
\hline Picolinic acid & Extraction & $75-96.6$ & 38 and 86 \\
\hline \multirow[t]{2}{*}{ Propionic acid } & Extraction & 75 & 21 \\
\hline & Adsorption & 64 & 18 \\
\hline Pyruvic acid & Extraction & $40-82$ & 87 and 88 \\
\hline \multirow[t]{3}{*}{ Succinic acid } & Extraction & $67-95$ & 40 and $89-91$ \\
\hline & Precipitation & 93.3 & 30 \\
\hline & Adsorption & $96-99$ & 57 and 62 \\
\hline \multirow[t]{2}{*}{ Tartaric acid } & Extraction & 90 & 23 \\
\hline & Adsorption & $75-99$ & 92 and 93 \\
\hline
\end{tabular}


Table 2 Comparison of the technologies for organic acid recovery

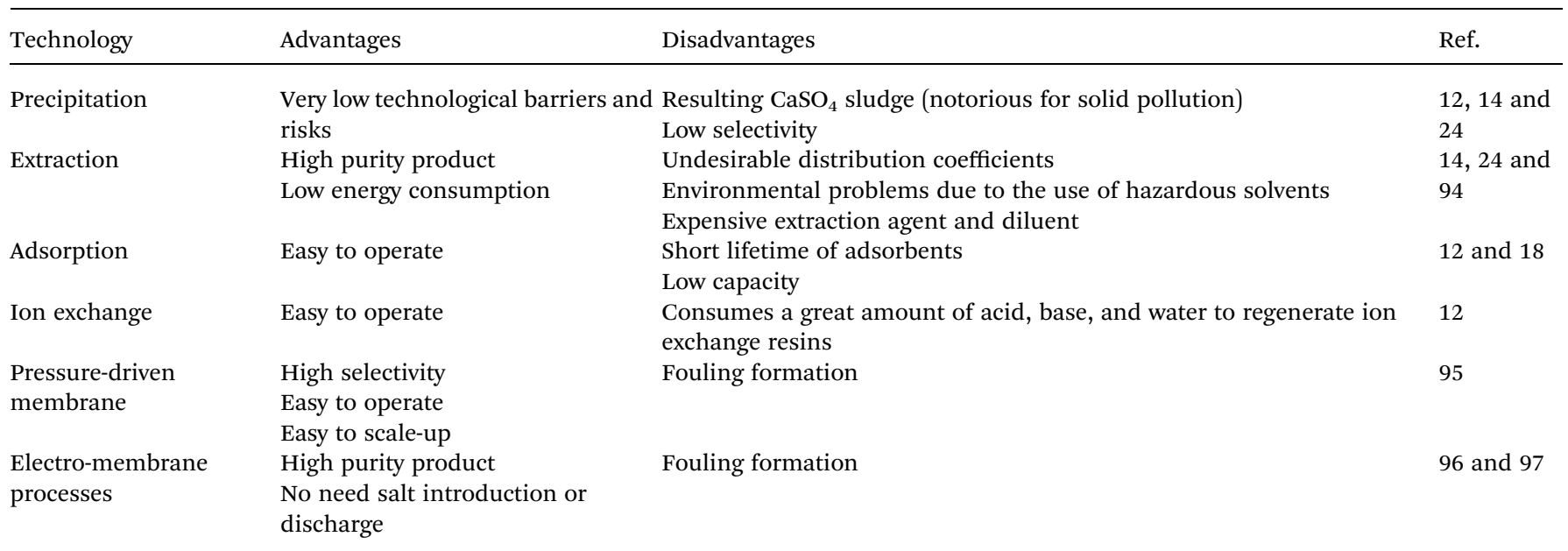

by anion and cation exchange membranes arranged between an anode and cathode, ${ }^{99}$ as shown in Fig. 2(a).

The ion-exchange membranes are made of a macromolecular material that carries ionic groups. ${ }^{102}$ The cation exchange membranes (CEM) possess negatively charged fixed groups and allow the migration of cations, while anion exchange membranes (AEM) possess positively charged fixed groups and allows the migration of anions. When a sufficient electrical field (a)

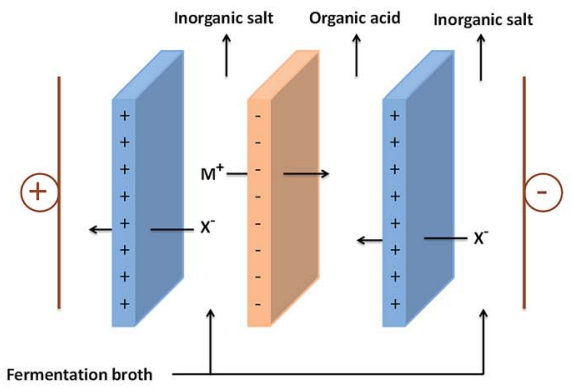

(c)

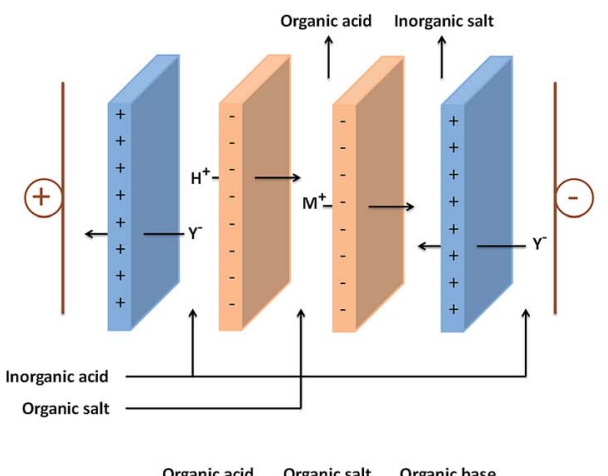

(e)

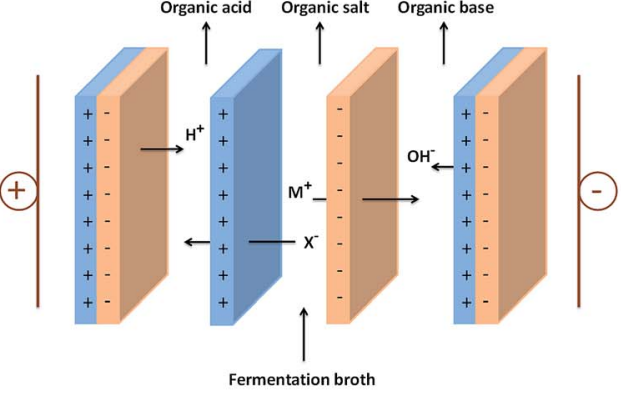

(b)

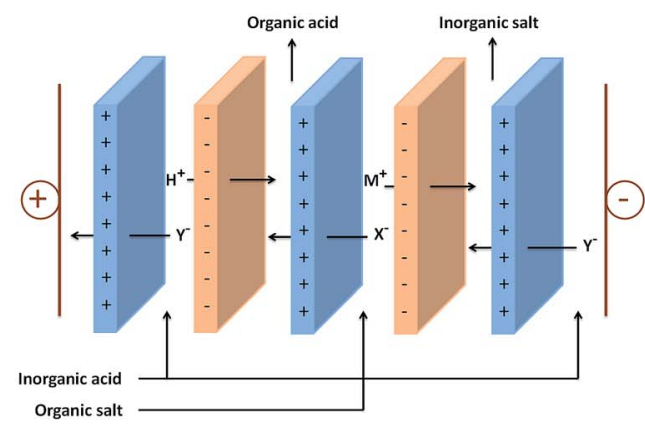

(d)

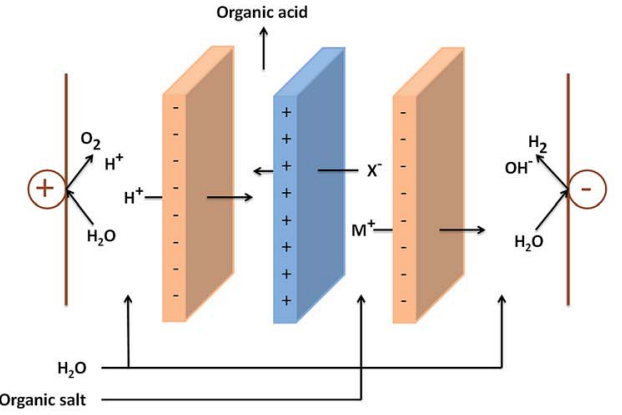

(f)

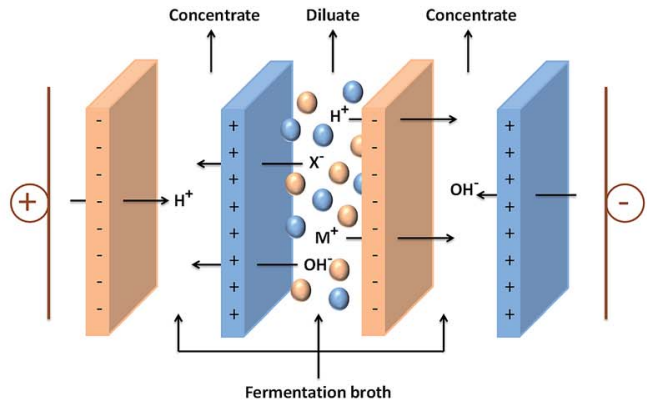

Fig. 2 Schematic of the stack configuration for: (a) ED, (b) EMT, (c) EIS, (d) EED, (e) EDBM, and (f) EDI to produce organic acids. 
is applied on the solution, the mobile ions are replaced by same charged ions (counter ion) from the solution and the membrane matrix will repel ions that have the same charge as the membrane matrix (co-ion). This mechanism allows the selective passage of ions. ${ }^{103}$

To recover organic acids from fermentation broth, the feed solution is circulated on each compartment of the ED system, while a potential difference is applied between the two electrodes. Due to the potential difference, positive ions (cations) migrate to the negative electrode (cathode), while the negative ions (anions) migrate to the positive electrode (anode). After some time, organic acids as ionic species are stripped from the diluate compartment and collected in the concentrate compartment. Uncharged molecules are not affected by this driving force, and hence organic acids can be separated from the uncharged components in the solution. ${ }^{\mathbf{1 0 4}}$

\section{Electrometathesis (EMT)}

EMT is a modified ED process, which has been used for the recovery of citric acid ${ }^{\mathbf{1 0 5}}$ and lactic acid. ${ }^{\mathbf{9 4 , 1 0 6}}$ Generally, an EMT process consists of four compartments formed by two alternately arranged anion exchange membranes and two cation exchange membranes with two types of feed streams and outputs, as shown in Fig. 2(b). EMT can realize double composition reactions that hardly occur in other conditions than that in ED systems. In EMT, inorganic acids such as $\mathrm{HCl}$ and $\mathrm{H}_{2} \mathrm{SO}_{4}$ are necessary for the conversion of organic salts into organic acids. ${ }^{12}$ The addition of strong acid such as $\mathrm{HCl}$ in the product compartment helps to facilitate the transport of ions. ${ }^{107}$

\section{Electro-ions substitution (EIS)}

EIS is another modified ED technique that consists of two adjacent cation-selective (or anion-selective) membranes, one anion-selective (or cation-selective) membrane, and three compartments, as shown in Fig. 2(c). EIS can realize substitution between ions of the same sign. The $\mathrm{H}^{+}$needed for ion substitution is supplied by an additional feed stream using an inorganic acid, such as $\mathrm{H}_{2} \mathrm{SO}_{4}$. At the beginning of the EIS process, a current efficiency of more than $100 \%$ can be reached due to $\mathrm{H}^{+} / \mathbf{M}^{+}$Donnan dialysis. However, more $\mathbf{M}^{+}$in the acid stream will compete with $\mathrm{H}^{+}$, and hence decrease the current efficiency. To suppress this competition, a cation-selective membrane with a higher $\mathrm{H}^{+} / \mathrm{M}^{+}$permselectivity can be added. ${ }^{12}$

\section{Electro-electrodialysis (EED)}

EED is an alternative methods that can be used to convert organic salt into organic acid due to its effective functional integration of ion exchange membranes and water splitting formed at the cathode and anode by reduction and oxidation. ${ }^{\mathbf{1 0 8}}$ A schematic representation of the EED process is presented in Fig. 2(d). In EED, the anion exchange membrane is essential since the acids are displaced by permselective transport of acid anions through the anion exchange membrane and electrodialysis of protons from the electrochemical reactions that occur at the electrodes. ${ }^{\mathbf{1 0 9 , 1 1 0}}$ This method was mainly used for the production of formic acid. ${ }^{\mathbf{1 1 0 , 1 1 1}}$ Formate anions $\left(\mathrm{HCOO}^{-}\right)$pass through the anion exchange membrane into the anolyte compartment. In this compartment, formic acid is formed by combining formate anions with the protons produced by anodic water oxidation. Meanwhile, $\mathrm{H}^{+}$is retained in the catholyte compartment and reacts with hydroxide ions to form water.

Besides formic acid, EED also has been used for the recovery of lactic acid, ${ }^{112}$ acetic acid, ${ }^{113}$ salicylic acid, ${ }^{114}$ glutamic acid, ${ }^{115}$ and propionic acid.16 Generally, the overall electrical current efficiencies of EED are much higher than that from conventional ED. However, the concentration ratio of the concentrated solutions is low, even less than 1.0. ${ }^{117}$ Therefore, some studies developed twophase electro-electrodialysis (TPEED) to improve the recovery ratio of the produced acid. TPEED has been used to recover citric acid ${ }^{\mathbf{1 1 7}}$ and lactic acid. ${ }^{\mathbf{1 1 2 , 1 1 8}}$ This method successfully increased the acid concentration ratio with half the energy consumption for EED.

\section{Electrodialysis with bipolar membranes (EDBM)}

To improve the separation performance of ED, several researchers combined the conventional ED and water dissociation of bipolar membranes, exploring a new avenue for the development of conventional ED. A bipolar membrane is a combination of a cation-selective and an anion-selective membrane; however, it has distinctive functions from that mono-polar membranes. Under a reverse potential bias, bipolar membranes can realize the dissociation of solvent molecules. ${ }^{12}$ EDBM can split and separate water into $\mathrm{H}^{+}$and $\mathrm{OH}^{-}$ions and the membranes can operate at about $80 \%$ of the theoretical thermodynamic efficiency. ${ }^{119}$ This technology also enables $\mathrm{H}^{+}$to be transported to the acid anion to form the free acid, while the $\mathrm{OH}^{-}$ion is transported to the cation compartment to form the free base. Therefore, separation efficiency and acid purity can be increased by the addition of bipolar membrane. Besides, the effluent (glucose, calcium, magnesium, etc.) from EDBM can be reused for fermentation after simple processing. However, the cost of membranes is still the main limitation for the large-scale application of EDBM. ${ }^{\mathbf{1 2 0}}$

For application in organic acid recovery, EDBM is mainly operated using a three-compartment configuration, as shown in Fig. 2(e). This configuration consists of brine, base, and acidcontaining streams. ${ }^{\mathbf{1 2 1}}$ The fermentation broth passes through the membrane stack in the brine compartment, which is placed between an anion and a cation exchange membrane. The compartment between the cation membrane and the anion side of the bipolar membrane is filled with the base stream, where hydroxide is generated. Meanwhile, the acid stream is placed between the anion membrane and the cation side of the bipolar membrane, where acid is generated. The anions are transported from the brine compartment to the acid compartment through the anion membrane, while cations are transported from the brine compartment to the base compartment through the cation membrane. In this configuration, hydrochloric acid and $\mathrm{Na} / \mathrm{K}$ hydroxide can be recovered in the acid and base compartments, respectively. ${ }^{\mathbf{1 0 2}}$

\section{Electrodeionization (EDI)}

EDI is a modified ED process with the presence of ion exchange resins between the anion and cation exchange membranes, as 
illustrated in Fig. 2(f). The presence of ion exchange resins enhances the ionic conductivity of a dilute solution by absorbing and concentrating the ions on the resin beads. Besides, the water splitting reaction on the resins surface enables in situ regeneration of the ion exchange resins and aids in the transport of ionic species across the ion exchange membranes. ${ }^{7}$ The water splitting reaction produces protons and hydroxyl ions at the resin-resin and resin-membrane interfaces. These ions continuously replace the adsorbed ions on the ion exchange resins surface; thus, resulting in more conductive ion exchange resins pathway. ${ }^{122}$ Thus, EDI offers a continuous process where ion exchange resins can be continuously regenerated by a direct current electric field. ${ }^{123}$ Due to its ability to produce high purity products, EDI is mainly applied for the production of ultrapure water. ${ }^{\mathbf{1 2 4 - 1 2 6}}$ However, several studies on the recovery of organic acids using EDI also have been established, such as the recovery of citric acid, ${ }^{7}$ amino acid, ${ }^{\mathbf{1 2 7}}$ butyric acid, ${ }^{128,129}$ and lactic acid. ${ }^{123}$

\section{Performance of organic acid recovery using electro-membrane processes}

For high productivity, fermentation-based processes require maintenance of near neutral $\mathrm{pH}$ and addition of alkali in most cases for the production of organic acids. The addition of alkali leads to the formation of organic salt instead of organic acid. To overcome this problem, electro-membrane processes have attracted the attention of several researchers since they do not require the addition of acid or alkali.

Table 3 summarizes the reported results for various electromembrane processes for the recovery of organic acids. Among the various organic acids, many researchers have focused on the recovery of lactic acid due to its multifunctional applications as a preservative in the food, pharmaceutical, leather, and textile industries, and a chemical feedstock..$^{130}$ The recovery of lactic acid has been conducted using ED, EIS, EDBM, and EDI. The results showed that these electro-membrane processes were able to recover more than $90 \%$ of lactic acid with a final concentration of up to $185 \mathrm{~g} \mathrm{~L}^{-1}$.

The electro-membrane process also gave good results for the recovery of other organic acids. ED and EDBM have been used for almost all organic acids. ED was able to recover $63-65 \%$ amino acid ${ }^{133}$ and tartaric acid, ${ }^{152} 85 \%$ of butyric acid, and more than $90 \%$ of glyceric acid ${ }^{140}$ and lactic acid. ${ }^{3,16,143}$ Meanwhile, EDBM has been used for the recovery of acetic acid, ${ }^{\mathbf{1 3 2}}$ amino acid, ${ }^{134,135}$ citric acid, ${ }^{137,138}$ fumaric acid, ${ }^{139}$ lactic acid, ${ }^{\mathbf{1 4 2}}$ malic acid, ${ }^{145}$ propionic acid, ${ }^{116}$ salicylic acid, ${ }^{121,146}$ and succinic acid. ${ }^{149}$ Most of the studies on EDBM mainly focused on the current efficiency, where the results showed that the current efficiency for organic acid recovery was affected by the EDBM stack configuration and feed characteristics.

Besides ED and EDBM, several researchers used EED for the recovery of acetic acid, formic acid, and propionic acid. Koter ${ }^{113}$ used EED for the separation of acetic acid, which resulted in a high acetic acid retention efficiency (>90\%) when the process was conducted at current densities lower than the limiting current density. Akgemci et al. ${ }^{\mathbf{1 1 0}}$ and Luo et al. ${ }^{111}$ investigated the current efficiency of EED for formic acid recovery and obtained a current efficiency of more than $100 \%$. The current efficiency of 90-99\% was obtained for the recovery of propionic acid by Boyaval et al. ${ }^{116}$ Meanwhile, EDI has been used for the recovery of amino acid, ${ }^{\mathbf{1 2 7}}$ butyric acid, ${ }^{\mathbf{1 2 8 , 1 2 9}}$ citric acid, ${ }^{7}$ and lactic acid. ${ }^{\mathbf{1 2 3}}$ The results showed that EDI is a potential technology for the recovery of organic acids with a high current efficiency and recovery rate.

In general, electro-membrane processes are feasible to recover organic acids with a high acid recovery ratio and low energy consumption. However, each electro-membrane process has advantages and disadvantages, as presented in Table 4. ED and EED are simple processes without the need for acid; however, their recovery rate and product concentration are relatively lower than other electro-membrane processes. EMT and EIS can realize double composition reactions but require strong acid to facilitate the transport of ions. Meanwhile, EDBM and EDI can obtain high acid purity. However, EDBM has not been industrialized widely due to the high price of bipolar membranes, while EDI requires pretreatment.

\section{Development of electro-membrane process designs for organic acid recovery}

The stack configuration plays an important role in the efficiency and recovery yield of electro-membrane processes. Several modifications of the electro-membrane configuration have been conducted to improve the recovery yield of organic acids for both the laboratory and industrial scales. Besides, the combined process of organic acid production and separation, which is mostly called the in situ separation process, also has been proposed to avoid product inhibition and degradation.

\section{Modification of electro-membrane configuration}

In his patent, Datta ${ }^{\mathbf{1 5 3}}$ designed an efficient and potentially economical process for lactic acid production. This process was configured to have desalting ED, water splitting electrodialysis (WSED), and ion-exchange purification steps. It was able to produce concentrated lactic acid with less than $0.1 \%$ of proteinaceous impurities from carbohydrate fermentation. In this process, there was no by-product gypsum and only a small amount of by-product salt was obtained from the ion-exchange regeneration. In addition, this process could be operated continuously, and thus can be scaled up for large-volume production.

In 1997, an EDBM plant for the recovery of organic acids was constructed in France. ${ }^{154}$ This plant produces 2600 ton organic acids per year with $98 \%$ purity. The process requires $0.88 \mathrm{~kW} \mathrm{~h}$ $\mathrm{kg}^{-1}$ of energy to produce acids. Generally, EDBM has the main problem of intolerance to multivalent cations such as $\mathrm{Ca}^{2+}$ and $\mathrm{Mg}^{2+}$, which form insoluble hydroxides at the critical interface of the bipolar membrane where the ions separate. The concentration of divalent cations is usually limited to about 1 ppm, while fermentation broths mostly contain multivalent 
Table 3 Performance of electro-membrane processes for the recovery of organic acids

Glyceric acid ED

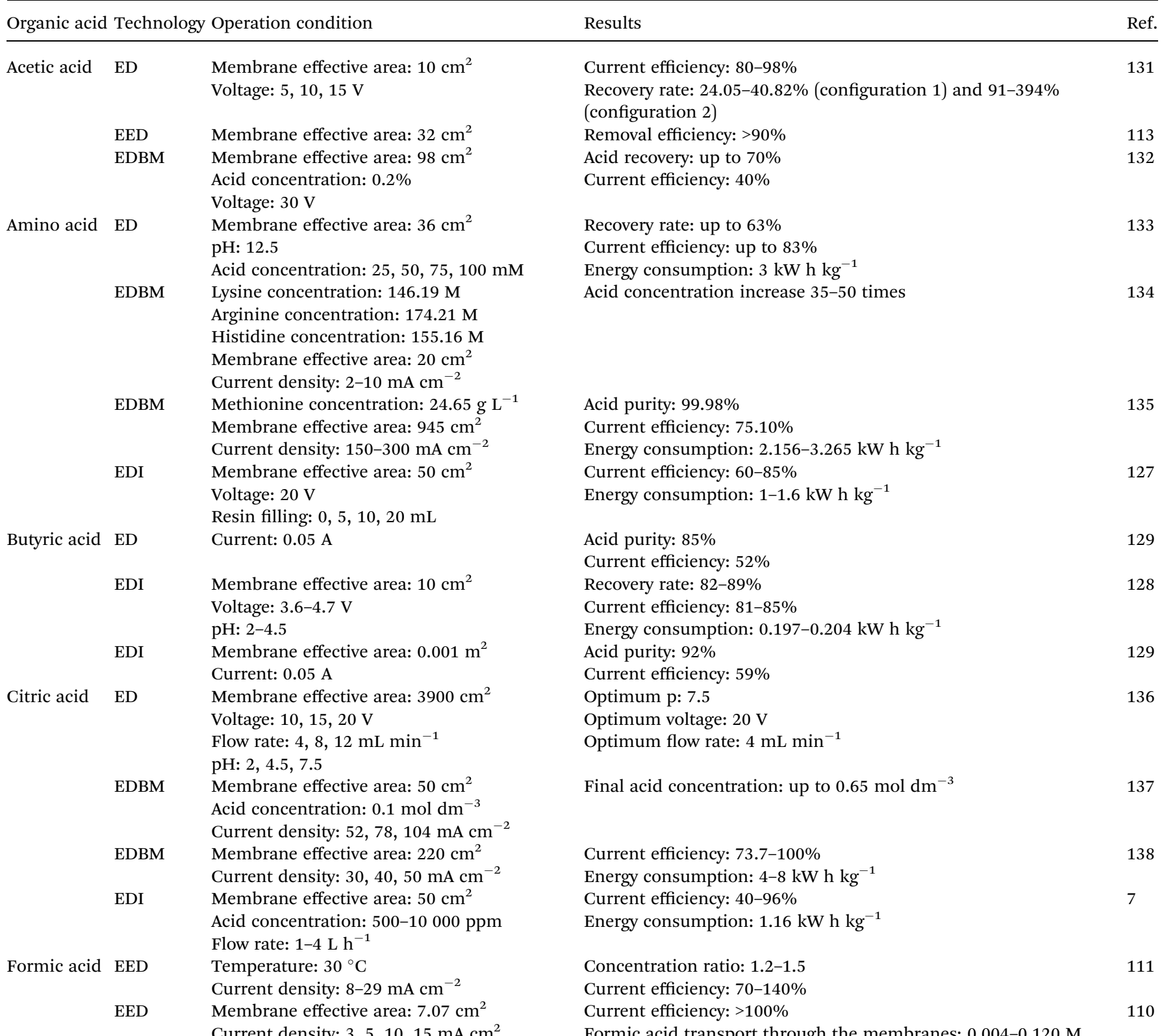

Temperature: $20-40{ }^{\circ} \mathrm{C}$

Acid concentration: $0.05-0.5 \mathrm{M}$

Anolyte and catholyte concentration: $0.1 \mathrm{M}$

Fumaric EDBM Membrane effective area: $0.0064 \mathrm{~m}^{2}$

acid Current density: $90,120,150 \mathrm{~mA} \mathrm{~cm}^{-2}$

Acid concentration: $1.45-2.90 \mathrm{~g} \mathrm{~L}^{-1}$

Circulation flow rate: $6.2 \mathrm{~L} \mathrm{~h}^{-1}$

Membrane effective area: $550 \mathrm{~cm}^{2}$ Acid concentration: $32.3-130.2 \mathrm{~g} \mathrm{~L}^{-1}$ $\mathrm{pH}: 7$

Lactic acid ED Membrane effective area: 58 and $180 \mathrm{~cm}^{2}$ Voltage: $1.5 \mathrm{~V}$

Current: $1.4 \mathrm{~A}$

ED Membrane effective area: $200 \mathrm{~cm}^{2}$ Acid concentration: $80-100 \mathrm{~g} \mathrm{dm}^{-3}$ Current: 8-12 A

Formic acid transport through the membranes: $0.004-0.120 \mathrm{M}$

131

113

32

Recovery ratio: up to $75 \%$

Current efficiency: $80-90 \%$

Energy consumption: 5-13 $\mathrm{kW} \mathrm{h} \mathrm{kg}^{-1}$

Acid recovery: $75-95 \%$

Current efficiency: $87.2-100 \%$

Energy consumption: $0.19-0.31 \mathrm{~kW} \mathrm{~h} \mathrm{~kg}^{-1}$

Current efficiency: $45-83 \%$

Final acid concentration: up to $157 \mathrm{~g} \mathrm{~L}^{-1}$

Energy consumption: $0.26-0.87 \mathrm{~kW} \mathrm{~h} \mathrm{~kg}^{-1}$

Acid recovery: 96.4-98.7\%

Current efficiency: $77.3-83.0 \%$

Energy consumption: 1.2-3.8

ED Feed: $0.1 \mathrm{~N}$ lactic acid and $0.1 \mathrm{~N}$ sodium sulfate Final acid concentration: up to $4 \mathrm{~g} \mathrm{~L}^{-1}$ Flow rate: $150 \mathrm{~mL} \mathrm{~min}^{-1}$

ED Membrane effective area: 57.6 and $180 \mathrm{~cm}^{2}$

Current efficiency: $66-84 \%$ 
Table 3 (Contd.)

Organic acid Technology Operation condition

Voltage: $1.5 \mathrm{~V}$

Current density: $7.8 \mathrm{~mA} \mathrm{~cm}{ }^{2}$

ED

Voltage: $0-15 \mathrm{~V}$

Acid concentration: $40 \mathrm{~g} \mathrm{~L}^{-1}$

ED Membrane effective area: $100 \mathrm{~cm}^{2}$

Acid concentration: $0,1,5 \mathrm{~g} \mathrm{~L}^{-1}$

Voltage: 10, 15, 20

Temperature: $32^{\circ} \mathrm{C}$

ED Voltage: $7 \mathrm{~V}$

Current density: $10-300 \mathrm{~A} \mathrm{~m}^{-2}$

EIS Membrane effective area: $25 \mathrm{~cm}^{2}$

Feed: $0.1 \mathrm{~N}$ lactic acid and $0.1 \mathrm{~N}$ sodium sulfate

Flow rate: $150 \mathrm{~mL} \mathrm{~min}^{-1}$

EDBM Membrane effective area: 57.6 and $180 \mathrm{~cm}^{2}$

Voltage: $12 \mathrm{~V}$

Current density: $67.7 \mathrm{~mA} \mathrm{~cm}{ }^{-2}$

EDI Membrane effective area: $90 \mathrm{~cm}^{2}$

Voltage: $0-70 \mathrm{~V}$

Current density: 0-45 $\mathrm{mA} \mathrm{cm}{ }^{-2}$

Acid concentration: $0-80 \mathrm{~g} \mathrm{~L}^{-1}$

Malic acid EDBM

Membrane effective area: $0.02 \mathrm{~m}^{2}$

Acid concentration: $24.4 \mathrm{~g} \mathrm{~L}^{-1}$

Circulation flow rate: $300 \mathrm{~L} \mathrm{~h}^{-1}$

Propionic EED Membrane effective area: $20 \mathrm{~cm}^{2}$

acid

Acid concentration: $40 \mathrm{~g} \mathrm{~L}^{-1}$

Current density: $70 \mathrm{~mA} \mathrm{~cm}{ }^{-2}$

EDBM Membrane effective area: $20 \mathrm{~cm}^{2}$

Acid concentration: $40 \mathrm{~g} \mathrm{~L}^{-1}$

Current density: $70 \mathrm{~mA} \mathrm{~cm}^{-2}$

Salicylic acid EDBM

Feed acid concentration: $1 \mathrm{M}$

Flow rate: $90 \mathrm{~L} \mathrm{~h}^{-1}$

Circulation rate: $4.6 \mathrm{~cm} \mathrm{~s}^{-1}$

Current density: 30, 50, $75 \mathrm{~mA} \mathrm{~cm} \mathrm{~cm}^{-2}$

EDBM Membrane effective area: $7.07 \mathrm{~cm}^{2}$

Acid concentration: 0.05-0.4 $\mathrm{mol} \mathrm{L}^{-1}$

Current density: $14-50 \mathrm{~mA} \mathrm{~cm}{ }^{-2}$

Succinic ED Membrane effective area: $178 \mathrm{~cm}^{2}$

acid

Acid concentration: $51.5 \mathrm{~g} \mathrm{~L}^{-1}$

ED Membrane effective area: $64 \mathrm{~cm}^{2}$

Voltage: 0-20 V

EDBM Membrane effective area: $80 \mathrm{~cm}^{2}$

Acid concentration: $0.05 \mathrm{M}$

Circulation rate: $15 \mathrm{~L} \mathrm{~h}^{-1}$

Current density: $12.5,25,37.5 \mathrm{~mA} \mathrm{~cm}^{-2}$

EDBM Membrane effective area: $80 \mathrm{~cm}^{2}$

Current density: $12.5-37.5 \mathrm{~mA} \mathrm{~cm}^{-2}$

EDBM

Membrane effective area: $207 \mathrm{~cm}^{2}$

Current density: 90 and $120 \mathrm{~A} \mathrm{~m}^{-2}$

Acid concentration: 43, 100, and $200 \mathrm{~g} \mathrm{~L}^{-1}$

EDBM Current density: 90 and $120 \mathrm{~mA} \mathrm{~cm}^{-2}$

Acid concentration: 15 and $16.9 \mathrm{~g} \mathrm{dm}^{-3}$

Feed flow rate: $100 \mathrm{dm}^{2} \mathrm{~h}^{-1}$

Tartaric acid ED

Results

Ref.

Final acid concentration: up to $173 \mathrm{~g} \mathrm{~L}^{-1}$

Energy consumption: $0.24-0.32 \mathrm{~kW} \mathrm{~h} \mathrm{~kg}^{-1}$

Acid recovery: $40-100 \%$

Energy consumption: $0.163-0.910 \mathrm{~kW} \mathrm{~h} \mathrm{~kg}^{-1}$

Acid recovery: up to $97 \%$

Energy consumption: $0.25 \mathrm{~kW} \mathrm{~h} \mathrm{~kg}^{-1}$

Mineral removal: $90 \%$

Energy consumption: $0.004-0.014 \mathrm{~kW} \mathrm{~h} \mathrm{~kg}^{-1}$

Final acid concentration: up to $9 \mathrm{~g} \mathrm{~L}^{-1}$

Current efficiency: 61-92\%

Final acid concentration: up to $173 \mathrm{~g} \mathrm{~L}^{-1}$

Energy consumption: $0.84-1.38 \mathrm{~kW} \mathrm{~h} \mathrm{~kg}^{-1}$

Final acid concentration: up to $185 \mathrm{~g} \mathrm{~L}^{-1}$

Current efficiency: $30 \%$

Energy consumption: $1.15-1.27 \mathrm{~kW} \mathrm{~h} \mathrm{~kg}^{-1}$

Current efficiency: 90.5-99.2\%

Final acid concentration: $150 \mathrm{~g} \mathrm{~L}^{-1}$

Current efficiency: $85.2-100 \%$

Final acid concentration: $145 \mathrm{~g} \mathrm{~L}^{-1}$

Current efficiency: 80-90\%

Final acid concentration: up to $45 \mathrm{M}$

Energy consumption: $14-38 \mathrm{~W} \mathrm{~h} \mathrm{~m} \mathrm{~kg}^{-1}$

Current efficiency: $99.6 \%$

Energy consumption: $2.1 \mathrm{~W} \mathrm{~h} \mathrm{~m}^{2} \mathrm{~kg}$

Current efficiency: $76.2-78.9 \%$

Current efficiency: $15-25 \%$

Total carboxylate basis: $50-60 \%$

Final acid concentration: $0.25-0.60 \mathrm{M}$

Current efficiency: $90 \%$

Energy consumption: $1-4 \mathrm{~kW} \mathrm{~h} \mathrm{~kg}{ }^{-1}$

Current efficiency: $96.8 \%$

Energy consumption: $<4 \mathrm{~kW} \mathrm{~h} \mathrm{~kg}{ }^{-1}$

Current efficiency: $75.4 \%$

Energy consumption: $1.5-3.2 \mathrm{~kW} \mathrm{~h} \mathrm{~kg}^{-1}$

Current efficiency: $14.3-19 \%$

Final acid concentration: 13 and $15.7 \mathrm{~g} \mathrm{dm}^{-3}$

Feed: $10 \mathrm{~kg} \mathrm{~m}^{-3}$ tartaric acid and $60 \mathrm{~kg} \mathrm{~m}^{-3}$ glucose

Current efficiency: $33-65 \%$

Final acid concentration: $170-300 \mathrm{~kg} \mathrm{~m}^{-3}$

Energy consumption: $5.103-12.103 \mathrm{~kJ} \mathrm{~kg}^{-1}$

cations with concentrations of up to $1000 \mathrm{ppm}$. Therefore, Datta and Henry ${ }^{\mathbf{1 1}}$ used desalting ED to remove the multivalent cations and concentrate the lactate salt, followed by treatment in a WSED unit with bipolar membranes to produce concentrated lactic acid and alkali for recycling. WSED is a general purpose unit operation for converting water-soluble salts to their corresponding acids and bases. ${ }^{\mathbf{1 5 5}}$ The results showed that 98-99\% of divalent ions were rejected with high recovery yield (>95\%) and low power consumption, giving approximately 0.33

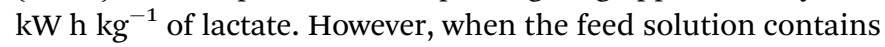


Table 4 Advantages and disadvantages of electro-membrane processes in organic acid recovery

Technology Advantages

ED Simple process, low energy consumption

EMT Can realize double composition reactions

EIS Can realize double composition reactions

EED High current efficiency, can be operated continuously

EDBM

EDI

High separation efficiency, high acid purity
Disadvantages

Relatively low recovery rate

Acid requirement

Low current efficiency, acid requirement

Low product concentration, low membrane stability and selectivity Expensive bipolar membrane price

High recovery rate, self-regeneration, can be operated continuously Requires pretreatment metal ions, such as calcium and magnesium, fouling occurs faster in WSED due to the precipitation of metal ions in the cation-exchange membrane. ${ }^{97}$

Another attempt was also investigated to increase the recovery efficiency by molding ion exchange resins into a porous resin wafer (RW) and inserting it into the electro-membrane stack. ${ }^{122,156,157}$ This modification is usually called resin wafer electrodeionization (RW-EDI). Compared to conventional EDI, RW-EDI provides simpler assembly and efficient operation. RWEDI demonstrates a very stable removal rate due to the rigidity of the porous wafer. Besides, the presence of a resin wafer enhances the electrical conductivity in the solutions and allows thinner EDI systems at reduced energy consumption, and regeneration of the resin wafers can occur within the cell through water splitting. ${ }^{158}$ Therefore, the use of resin wafer broadens the applications of EDI, such as for esterification, ${ }^{159}$ enzyme-based conversion and recovery of organic acids, ${ }^{156}$ and capture of carbon dioxide from flue gas. ${ }^{160}$ Datta et al. ${ }^{122}$ reported that RW-EDI successfully removed greater than $99 \%$ and $95 \%$ of sulfuric acid and acetic acid, respectively, while sugar retention was greater than $98 \%$.

Furthermore, Lopez et al. ${ }^{158,161}$ used ionic liquids instead of a resin wafer. They used two types of ionic liquid, including 1ethyl-3-methylimidazolium-trifluoromethanesulfonate ([EMIM] [OTf]) and 1-butyl-3-methylimidazolium acetate ([BMIM][OAc]). By using ionic liquids as the wafer in EDI stacks, they were able to obtain a recovery rate of $99 \%$, while the current efficiencies reached $37-90 \%$ with energy consumption rates of approximately $1.25-2.80 \mathrm{~kW} \mathrm{~h} \mathrm{~kg}^{-1}$ acid recovered.

\section{In situ separation processes}

Many fermentation processes have low productivity and yield due to product inhibition or hydrolysis of the product by further catalytic reactions. ${ }^{162}$ This problem can be solved by optimizing technological parameters, for example by keeping the dissolved product concentration as low as possible in the fermentation medium. Thus, the in situ separation process is promising for selectively removing the fermentation product from the vicinity of the biocatalyst as soon as it is formed and also increasing the efficiency of recovery processes. ${ }^{123}$

The in situ separation process is a combination of product formation and separation of organic acids. This process has been studied by several researchers with various schemes and designs. Arora et al. ${ }^{156}$ compared two schemes of combined bioreactor and EDI. The first scheme was called side-stream bioreactor, while the second was named immobilized separative bioreactor, as shown in Fig. 3. In the first scheme, the reaction takes place in a traditional bioreactor containing biocatalysts (enzymes/cells), sugars, and the organic acid products all in solution, which is then fed to the EDI separation unit. In the second scheme, the biocatalyst is immobilized directly in the RW-EDI to enable simultaneous reaction and separation. The results showed that immobilized separative bioreactor had a stable reaction rate, while the reaction rate decreased as a function of $\mathrm{pH}$ in the side-stream bioreactor.

Gao et al. ${ }^{163}$ studied the use of electrodialysis fermentation (EDF) for lactic acid production. In EDF, the fermentation broth is continuously fed to the ED to concentrate the organic acid. The solution with a high concentration of organic acid is collected as the product, while the solution with a low organic acid concentration is returned to the fermentation reactor. Using EDF, the acid productivity was 1.5 times higher than the convention fermentation-ED process. The yield also increased by above $30 \%$ and glucose transport decreased from 0.46 to 0.05 . Hirata et al. ${ }^{164}$ also used an EDF system equipped with a glucose concentration controller (GC controller). The GC controller was added to control the glucose concentration to be stable and low in the fermentation broth. Meanwhile, Danner et al. ${ }^{165}$ studied integrated continuous cell recycle cultivation using ultra-filtration membrane bioreactor (MBR) systems. The permeate from the MBR was streamed to an ED to recover and concentrate lactic acid. The recovery yield of lactic acid was stable at around $80 \%$ with the energy consumption of $0.49 \mathrm{~kW} \mathrm{~h} \mathrm{~kg}^{-1}$ of lactic acid.

Kumar et al. used an electro-membrane reactor where ion substitution and separation of acids occurred simultaneously for the recovery of glutamic acid ${ }^{15}$ and amino acid. ${ }^{166}$ Their studies resulted in a high recovery of glutamic acid and amino acid close to $96 \%$ and $85 \%$, respectively. Meanwhile, Liu et al. ${ }^{167}$ investigated the potential of an integrated EDBM and biochemical process named the microbial electrodialysis and chemical-production cell (MEDCC) to produce malic acid. In general, MEDCC has same operating system with EDF; however, MEDCC uses bipolar membranes, as shown in Fig. 3(d). Liu et al. ${ }^{167}$ showed that MEDCC could convert $0.3 \mathrm{M}$ malate into $0.23 \mathrm{M}$ malic acid with a low energy consumption of $0.34 \mathrm{~kW} \mathrm{~h}$ $\mathrm{kg}^{-1}$. This energy consumption was only $10-30 \%$ of that in the reported EDBM. The same method was also used by Wang et al. ${ }^{168,169}$ for the production of lactic acid. The productivity of lactic acid was $1.76 \mathrm{~g} \mathrm{~L}^{-1} \mathrm{~h}^{-1}$ and the yield coefficient was $56.77 \%$. In addition, Luo et al. ${ }^{170}$ also used MEDCC for the production of citric acid. The maximum citric acid production of $0.443 \pm 0.096 \mathrm{M}$ was achieved within $96 \mathrm{~h}$ operation. The 
(a)

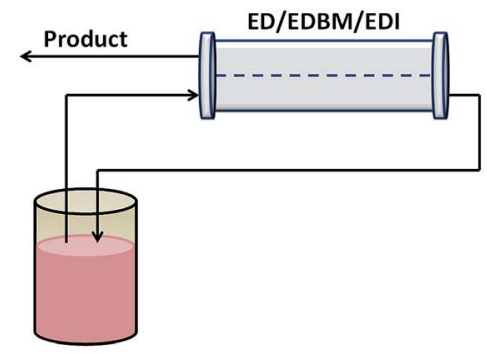

Enzyme and sugar 4

(c)

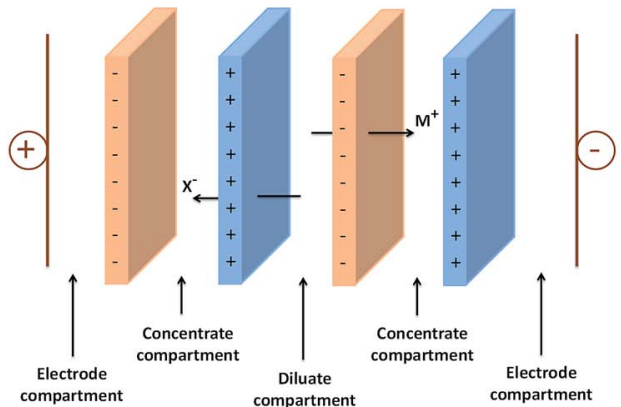

(b)

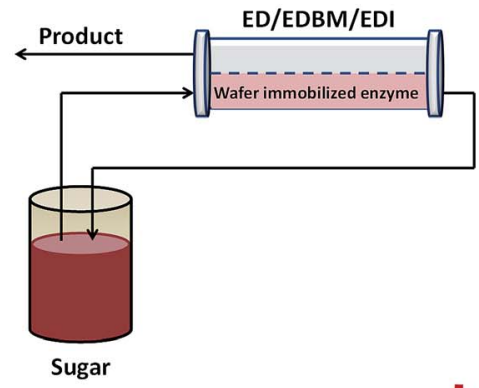

(d)

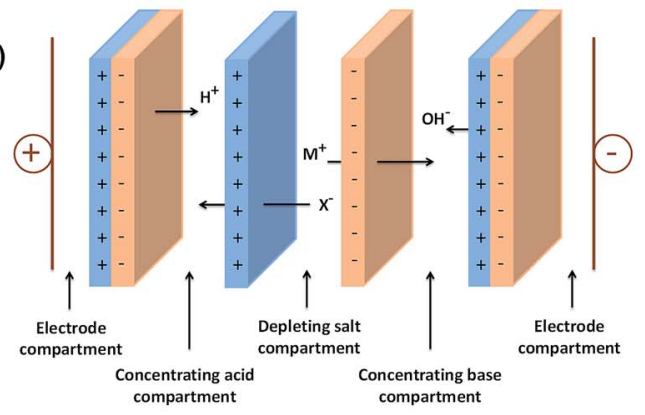

Fig. 3 Schematic of (a) a side-stream bioreactor, (b) an immobilized separative bioreactor, (c) the stack configuration for EDF, and (d) the stack configuration of MEDCC.

energy consumption was $0.81 \pm 0.03 \mathrm{~kW} \mathrm{~h} \mathrm{~kg}^{-1}$. Lu et al. ${ }^{171}$ also used MEDCC to produce formic acid. The minimum electricity consumption to produce $0.34 \pm 0.04 \mathrm{~kW} \mathrm{~h} \mathrm{~kg}^{-1}$ of formic acid in the MEDCC with $72 \mathrm{~cm}$ of the anode fiber length was only $3.1-18.8 \%$ of that in the EDBM.

In addition, Zhu et al. ${ }^{172}$ developed a new of bioelectrochemical system called a microbial reverse-electrodialysis chemical-production cell (MRCC). This system was developed to produce acid and alkali using energy derived from organic matter (acetate) and salinity gradients ( $\mathrm{NaCl}$ solutions representative of seawater and river water). A bipolar membrane was placed next to the anode to prevent $\mathrm{Cl}^{-}$contamination and acidification of the anolyte, and to produce protons for $\mathrm{HCl}$ recovery. The MRCC reactor produced electricity (908 $\mathrm{mW} \mathrm{m}^{-2}$ ) as well as concentrated acidic and alkaline solutions, and therefore did not require an external power supply. The results showed that the acid and alkali-production efficiencies based on the generated current were $58 \pm 3 \%$ and $25 \pm 3 \%$, respectively.

Fig. 4 shows a comparison of the energy consumption for various electro-membrane processes for organic acids, including separated downstream processes and in situ separation processes. It can be seen that the in situ separations such as EDF and MEDCC require much lower energy consumption, and thus are more promising to be developed on an industrial scale. However, the maximum current density of EDF and MEDCC is much lower than that of ED, which greatly limits their application in practice.

\section{Integrated separation processes}

Fermentation operates most efficiently and effectively at near neutral $\mathrm{pH}$, and hence produces the acid salt instead of the acid itself. Besides, the presence of impurities such as water, particles, microbial cells, unconverted carbon sources, and inorganic ions cannot be avoided. Therefore, the pretreatment of feed solution is important before pumping it into the electromembrane stack to ensure stable operation and process performance. Press filtration and UF membrane are the alternative technologies to remove particles or colloids (bacteria, cellulose, proteins, or suspended solid chemicals) and keep the electro-membrane stack free from serious membrane fouling. ${ }^{142,173}$ Activated carbon can be used to clear up coloring matter to prevent fouling or the appearance of unfavorable byproducts. $^{\mathbf{1 7 4}}$ Meanwhile, chelating resins are able to

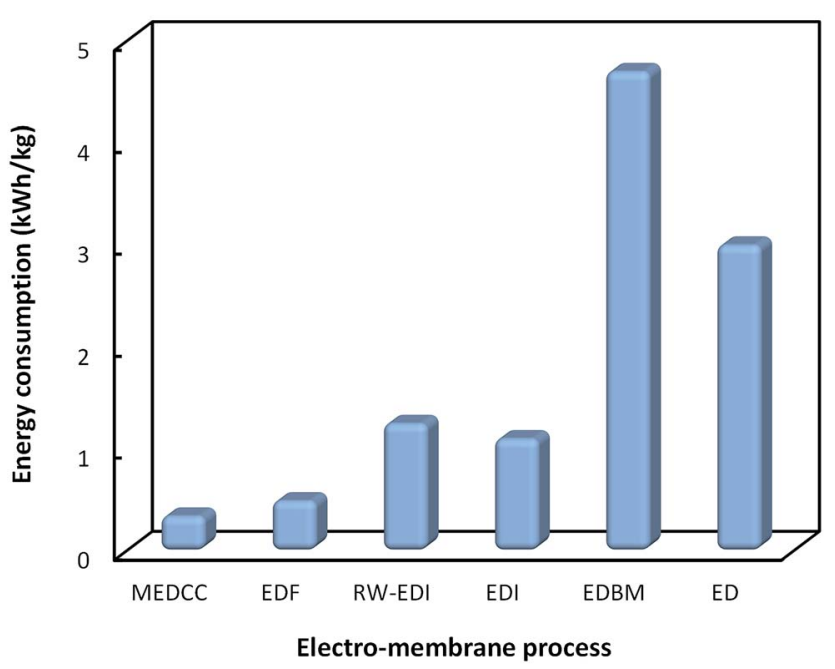

Fig. 4 Comparison of energy consumption for various electromembrane processes for the production of organic acids. 
selectively remove multivalent inorganic ions (especially, $\mathrm{Ca}^{2+}$, $\mathrm{Mg}^{2+}, \mathrm{Ba}^{2+}, \mathrm{Mn}^{2+}, \mathrm{Zn}^{2+}, \mathrm{Fe}^{3+}$, and $\mathrm{Sr}^{2+}$ ) to prevent scale formation. ${ }^{142,175,176}$

Boyaval et al. ${ }^{177}$ produced lactic acid in a continuous process comprising three distinct operations in a bioreactor, UF module, and ED cell. UF recycled all or part of the biomass and separated low molecular weight metabolites, such as sodium lactate, which resulted from lactose fermentation. The product of UF was then extracted and concentrated continuously by ED. This process was able to yield lactate solution in a high concentration of up to $130 \mathrm{~g} \mathrm{~L}^{-1}$. Meanwhile, Sikder et al. ${ }^{71}$ demonstrated that combined NF-EDBM in downstream purification is able to replace multiple purification steps with only two steps, while yielding monomer grade lactic acid from a mixture of unconverted sugars and lactic acid. NF also led to nearly total discoloration of the fermentation broth.

Bailly et al. ${ }^{176}$ proposed a complete organic acid production using a membrane for clarification, concentration and conversion. The fermentation broth was first clarified by cross-flow MF. Divalent cations were then removed from the clarified broth since they act as a poison in the process. ED was further used prior to EDBM to increase the concentration of ionic species comprising the organic acid salt. Meanwhile, Norddahl $^{178}$ combined UF and a two-step ED process. The first step used conventional ED membranes, while the second ED process used a bipolar membrane. A bipolar membrane was applied to separate the salts formed into lactic acid, inorganic acids, and ammonium hydroxide solution. By combining UF and two-step $\mathrm{ED}$, the overall recovery rate of lactic acid was quite high at about $85-90 \%$. Madzingaidzo et al. ${ }^{174}$ also combined ED and EDBM. ED was used for sodium lactate purification, while the recovery of lactic acid was done using EDBM. Sodium lactate with a feed concentration of $125 \mathrm{~g} \mathrm{~L}^{-1}$ was concentrated by ED to a maximum of $150 \mathrm{~g} \mathrm{~L}^{-1}$. The lactate solution was then passed through EDBM to obtain free lactic acid. The EDBM unit was able to obtain $160 \mathrm{~g} \mathrm{~L}^{-1}$ free lactic acid while color and other chemical impurities were significantly reduced. Later, further development based on this process involved adjustment of the $\mathrm{pH}$ to below the $\mathrm{p} K_{\mathrm{a}}$-value of lactic acid (3.86). ${ }^{179}$ As a result, the free lactate ions combined with hydrogen ions to form lactic acid having no net electrical charge. In 2018, Prochaska et al. ${ }^{151}$ proposed an integrated system consisting of UF, EDBM, and three steps reactive extraction for the removal of succinic acid. UF acted as pre-clarification to remove high molecular contaminants. Meanwhile, EDBM allowed the acidification of the broth to be eliminated. The succinic acid present in the aqueous stream after EDBM was then removed in a threestep reactive extraction at more than $90 \%$ efficiency.

The downstream process on the industrial scale is mostly more complicated than the laboratory scale. As example, lactic acid is separated and substantially purified from fermentation broths by several membrane-based unit operations. MF or UF are used for cell separation and recycle, while NF is essential for separation of the lactic acid from other broth components using low rejection (LR) membranes. ${ }^{180}$ Meanwhile, to concentrate the lactate, $\mathrm{RO}$ or a combination of high rejection (HR) and low rejection (LR) NF can be used. Further, ED is added for the simultaneous separation and concentration of lactate. The lactate product of ED is still in the salt form, and hence, EDBM is required to form lactic acid in the acid form and allow the recycle of the alkali used for neutralizing the fermentation broth. By adding EDBM to the process, the alkali cost is minimized, while the waste products (e.g., calcium sulfate) generated in conventional downstream processes for organic acids are eliminated. ${ }^{176}$

\section{Future prospect and challenges}

The increasing demand for organic acids in various applications has led to further exploration for their efficient production. The development of recovery processes is one of the crucial approaches to obtain efficient organic acid production with high quality product. The separation methods that have been studied for the recovery of organic acids mainly include precipitation, extraction, adsorption, and nanofiltration. Unfortunately, the existing processes still have many obstacles that need to be addressed. Precipitation and liquid-liquid extraction need a large amount of chemical agents and energy. They produce a large amount of water effluent as well as solid residue and involve phase changes that lead to a degradation in the quality of citric acid. Meanwhile, adsorption has a short lifetime of adsorbents and low capacity.

Electro-membrane processes are the promising technologies to replace the conventional technologies for the organic acid downstream process. Electro-membrane processes such as ED, EMT, EIS, EED, EDBM, and EDI can recover organic acids from their fermentation broth without the introduction of salt or discharge. Besides, their energy consumption is much lower than conventional technologies. However, concentration polarization and fouling are still main issues in electromembrane processes. The concentration polarization is a result of the difference between the transport number of the ions in the membrane and in the feed solution. These phenomena then lead to an accumulation of ions on the membrane surface in concentrate compartment, while ion depletion occurs on the membrane surface in the diluate compartment. ${ }^{181}$ As a consequence, the operating currents of electro-membrane processes are restricted by the occurrence of concentration polarization.

In addition, fouling also undeniably occurs during membrane operation. Fouling is associated with the accumulation of substances on the membrane surface or within the membrane pores. ${ }^{182}$ Fouling not only leads to a decline in productivity, but also requires an additional energy supply to keep the membrane performance constant. ${ }^{\mathbf{1 8 3 - 1 8 6}}$ In electromembrane processes, fouling occurs due to the accumulation of colloids and organic substances. Colloidal fouling is mainly deposited on the AEM since most of the colloids treated by electro-membrane processes are negatively charged, which leads to interactions with positively charged ion-exchange groups of AEM. Meanwhile, organic substances stick to the surface of all types of membranes and/or lodge themselves inside the membrane. In colloidal fouling, the interaction of the foulant and membrane is only electrostatic in nature, while 
organic fouling on the IEM surface and inside the IEM may be due to electrostatic and hydrophobic interactions. ${ }^{187}$

Fouling and concentration polarization are inevitable but can be controlled. The usage of suitable strategies allows for a longer membrane life and lower operational costs. Various attempts can be undertaken to control fouling and concentration polarization, such as selection of appropriate pretreatment, modification of the membrane, and optimization of operation conditions by increasing the $\mathrm{pH}$ and cross flow velocity, or decreasing the initial flux. Selection of an appropriate pretreatment can be used to inhibit the fouling and concentration polarization by reducing the concentration of impurities in the feed water. Meanwhile, optimization of the operation can minimize the interaction between impurities/foulant and the membrane surface. As an example, an increase in cross flow velocity can reduce fouling due to the disruption of the fouling layer by a strong hydrodynamic shear rate. ${ }^{188}$ In addition, the properties of membrane materials plays an important role in fouling formation. Hydrophobic membranes are more prone to fouling formation than hydrophilic membranes. Therefore, in several cases, hydrophilic modification is required. Hydrophilic modification can be conducted by blending the original polymer with hydrophilic materials or the addition of hydrophilic polymer layers on the active surface of the membrane. ${ }^{\mathbf{1 8 9 - 1 9 3}}$

Furthermore, there is still a need for further research to develop processes that are simple to carry out and allow the purification of organic acids directly from the fermentation broth. The integrated process of fermentation and product recovery, which is usually called in situ separation, is an alternative to solve this problem. The integration of fermentation and the electro-membrane process can increase the recovery yield to above $30 \%$, while decreasing the energy consumption by at least $90 \%$. However, this separation process still has room for improvement to make it industrially feasible, including the development of membrane materials, process design, and optimization of operating conditions.

\section{Conflicts of interest}

There are no conflicts to declare.

\section{References}

1 D. d. B. Richter, N.-H. Oh, R. Fimmen and J. Jackson, in The Rhizosphere, ed. J. L. Whitbeck, Academic Press, Burlington, 2007, pp. 179-200.

2 W. Zhao, X. Sun, Q. Wang, H. Ma and Y. Teng, Biomass Bioenergy, 2009, 33, 21-25.

3 Y. H. Kim and S. H. Moon, J. Chem. Technol. Biotechnol., 2001, 76, 169-178.

4 R. Datta, S. P. Tsai, P. Bonsignore, S. H. Moon and J. R. Frank, FEMS Microbiol. Rev., 1995, 16, 221-231.

5 T. Kurzrock and D. Weuster Botz, Biotechnol. Lett., 2010, 32, 331-339.

6 H. Takahashi, K. Ohba and K. Kikuchi, J. Membr. Sci., 2003, 222, 103-111.
7 I. N. Widiasa, P. D. Sutrisna and I. G. Wenten, Sep. Purif. Technol., 2004, 39, 89-97.

8 A. Shishikura, K. Kanamori, H. Takahashi and H. Kinbara, J. Agric. Food Chem., 1994, 42, 1993-1997.

9 H. Takahashi, K. Ohba and K. Kikuchi, Biochem. Eng. J., 2003, 16, 311-315.

10 J. S. J. Ferrer, S. Laborie, G. Durand and M. Rakib, J. Membr. Sci., 2006, 280, 509-516.

11 R. Datta and M. Henry, J. Chem. Technol. Biotechnol., 2006, 81, 1119-1129.

12 C. Huang, T. Xu, Y. Zhang, Y. Xue and G. Chen, J. Membr. Sci., 2007, 288, 1-12.

13 I. Bechthold, K. Bretz, S. Kabasci, R. Kopitzky and A. Springer, Chem. Eng. Technol., 2008, 31, 647-654.

14 Q. Z. Li, X. L. Jiang, X. J. Feng, J. M. Wang, C. Sun, H. B. Zhang, M. Xian and H. Z. Liu, J. Microbiol. Biotechnol., 2016, 26, 1-8.

15 I. H. Aljundi, J. M. Belovich and O. Talu, Chem. Eng. Sci., 2005, 60, 5004-5009.

16 W. Boonkong, P. Sangvanich, A. Petsom and N. Thongchul, Chem. Eng. Technol., 2009, 32, 1542-1549.

17 X. Cao, H. S. Yun and Y. M. Koo, Biochem. Eng. J., 2002, 11, 189-196.

18 A. H. da Silva and E. A. Miranda, J. Chem. Eng. Data, 2013, 58, 1454-1463.

19 K. Zhang, L. Zhang and S. T. Yang, Ind. Eng. Chem. Res., 2014, 53, 12802-12808.

20 M. T. Gao, T. Shimamura, N. Ishida, E. Nagamori, H. Takahashi, S. Umemoto, T. Omasa and H. Ohtake, Enzyme Microb. Technol., 2009, 44, 350-354.

21 A. Keshav, K. L. Wasewar and S. Chand, Chem. Eng. Commun., 2009, 197, 606-626.

22 S. J. Li, H. L. Chen, J. Y. Xu and L. Zhang, Sep. Sci. Technol., 2007, 42, 2347-2360.

23 M. Marinova, G. Kyuchoukov, J. Albet, J. Molinier and G. Malmary, Sep. Purif. Technol., 2004, 37, 199-207.

24 K. K. Cheng, X. B. Zhao, J. Zeng, R. C. Wu, Y. Z. Xu, D. H. Liu and J. A. Zhang, Appl. Microbiol. Biotechnol., 2012, 95, 841850.

25 L. G. Heding and J. K. Gupta, Biotechnol. Bioeng., 1975, 17, 1363-1364.

26 R. Karklin, L. Ramina and R. Raso, Biosint. Oksikilot Ketokislot Mikroorg., 1984, 43-51.

27 D.-J. Min, K. H. Choi, Y. K. Chang and J.-H. Kim, Korean J. Chem. Eng., 2011, 28, 1969.

28 K. A. Berglund, P. Elankovan and D. A. Glassner, Carboxylic acid purification and crystallization process, US Pat. no. 5,034,105, 23 Jul. 1991.

29 R. Datta, et al., Fermentation and purification process for succinic acid, US Pat. no. 5,168,055, 1 Dec. 1992.

30 B. Norddahl, Fermentative production and isolation of lactic acid, US Pat. no. 6,319,382, 20 Nov. 2001.

31 A. Demirci, A. L. Pometto and K. R. Harkins, Bioseparation, 1998, 7, 297-308.

32 M. Pazouki and T. Panda, Bioprocess Eng., 1998, 19, 435439. 
33 T. Harington and M. M. Hossain, Desalination, 2008, 218, 287-296.

34 Y. K. Hong and W. H. Hong, Sep. Purif. Technol., 2005, 42, 151-157.

35 S. P. R. Katikaneni and M. Cheryan, Ind. Eng. Chem. Res., 2002, 41, 2745-2752.

36 A. Labbaci, G. Kyuchoukov, J. Albet and J. Molinier, J. Chem. Eng. Data, 2010, 55, 228-233.

37 A. M. Baniel and D. Gonen, Production of citric acid, US Pat. no. 4,994,609, 19 Feb. 1991.

38 A. F. Tuyun, H. Uslu, S. Gökmen and Y. Yorulmaz, J. Chem. Eng. Data, 2011, 56, 2310-2315.

39 Y. K. Hong and W. H. Hong, Bioprocess Eng., 2000, 22, 477481.

40 Y.-S. Jun, E. Z. Lee, Y. S. Huh, Y. K. Hong, W. H. Hong and S. Y. Lee, Biochem. Eng. J., 2007, 36, 8-13.

41 H. G. Joglekar, I. Rahman, S. Babu, B. D. Kulkarni and A. Joshi, Sep. Purif. Technol., 2006, 52, 1-17.

42 P. von Frieling and K. Schügerl, Process Biochem., 1999, 34, 685-696.

43 M. Jarvinen, L. Myllykoski, R. Keiski and J. Sohlo, Bioseparation, 2000, 9, 163-166.

44 H. Honda, Y. Toyama, H. Takahashi, T. Nakazeko and T. Kobayashi, J. Ferment. Bioeng., 1995, 79, 589-593.

45 G. Yang, M. S. Jahan, L. Ahsan, L. Zheng and Y. Ni, Bioresour. Technol., 2013, 138, 253-258.

46 L. Ahsan, M. S. Jahan and Y. Ni, Ind. Eng. Chem. Res., 2013, 52, 9270-9275.

47 H. Demiral and M. Ercengiz Yildirim, Water Sci. Technol., 2003, 47, 183-188.

48 C. B. Rasrendra, B. Girisuta, H. H. van de Bovenkamp, J. G. M. Winkelman, E. J. Leijenhorst, R. H. Venderbosch, M. Windt, D. Meier and H. J. Heeres, Chem. Eng. J., 2011, 176-177, 244-252.

49 S. Kumar and B. Babu, i-Manager's J. Future Eng. Technol., 2008, 3, 21.

50 Y. K. Hong, W. H. Hong and D. H. Han, Biotechnol. Bioprocess Eng., 2001, 6, 386.

51 Z. Gu, D. A. Rickert, B. A. Glatz and C. E. Glatz, Le Lait, 1999, 79, 137-148.

52 A. Keshav, K. L. Wasewar and S. Chand, Desalination, 2009, 244, 12-23.

53 I. Inci, S. S. Bayazit and Y. S. Asci, J. Chem. Eng. Data, 2011, 56, 4449-4453.

54 C. Efe, M. Pieterse, L. A. M. van der Wielen and A. J. J. Straathof, Chem. Eng. Process., 2011, 50, 1143-1151.

55 C. C. Chen and L. K. Ju, Sep. Sci. Technol., 1998, 33, 14231437.

56 E. Ponnampalam, Purification of organic acids using anion exchange chromatography, US Pat. no. 6,284,904, 4 Sep. 2001.

57 Q. Li, J. Xing, W. Li, Q. Liu and Z. Su, Ind. Eng. Chem. Res., 2009, 48, 3595-3599.

58 W. Y. Tong, X. Y. Fu, S. M. Lee, J. Yu, J. W. Liu, D. Z. Wei and Y. M. Koo, Biochem. Eng. J., 2004, 18, 89-96.

59 Y. R. A. González-Vara, G. Vaccari, E. Dosi, A. Trilli, M. Rossi and D. Matteuzzi, Biotechnol. Bioeng., 2000, 67(2), 147-156.
60 A. Srivastava, P. K. Roychoudhury and V. Sahai, Biotechnol. Bioeng., 1992, 39, 607-613.

61 G. Raya Tonetti, P. Córdoba, J. Bruno-bárcena, F. Siñeriz and N. Perotti, Biotechnol. Tech., 1999, 13, 201-205.

62 N. Cao, J. Du, C. Gong and G. Tsao, Appl. Environ. Microbiol., 1996, 62, 2926-2931.

63 Y. Zheng, X. Ding, P. Cen, C. W. Yang and G. T. Tsao, Appl. Biochem. Biotechnol., 1996, 57, 627.

64 H. J. Lee, Y. Xie, Y. M. Koo and N. H. L. Wang, Biotechnol. Prog., 2004, 20, 179-192.

65 C. Chen and L. K. Ju, Appl. Microbiol. Biotechnol., 2002, 59, 170-174.

66 C. Umpuch, S. Galier, S. Kanchanatawee and H. R.-d. Balmann, Process Biochem., 2010, 45, 1763-1768.

67 B. Van der Bruggen, J. Schaep, D. Wilms and C. Vandecasteele, J. Membr. Sci., 1999, 156, 29-41.

68 M. I. Gonzalez, S. Alvarez, F. A. Riera and R. Alvarez, Desalination, 2008, 228, 84-96.

69 M. S. Kim, J. G. Na, M. K. Lee, H. Ryu, Y. K. Chang, J. M. Triolo, Y. M. Yun and D. H. Kim, Water Res., 2016, 96, 208-216.

70 S. H. Kang, Y. K. Chang and H. N. Chang, Biotechnol. Prog., 2004, 20, 764-770.

71 J. Sikder, S. Chakraborty, P. Pal, E. Drioli and C. Bhattacharjee, Biochem. Eng. J., 2012, 69, 130-137.

$72 \mathrm{Z}$. Yao, et al., Method for separation succinic acid from anaerobic fermentation broth, Chinese Patent, CN200610086003.7, 2008.

$73 \mathrm{H}$. Wu, et al., Nanofiltration method for separation of succinic acid from its fermented broth, Chinese Patent, CN200910025531.5, 2011.

74 Y. Li and A. Shahbazi, in Twenty-Seventh Symposium on Biotechnology for Fuels and Chemicals, ed. J. D. McMillan, W. S. Adney, J. R. Mielenz and K. T. Klasson, Humana Press, Totowa, NJ, 2006, pp. 985-996.

75 H. Y. Yu, L. Q. Liu, Z. Q. Tang, M. G. Yan, J. S. Gu and X. W. Wei, J. Membr. Sci., 2008, 311, 216-224.

76 A. M. Islam, Master thesis, Chalmers University of Technology, Gothenburg, Sweden, 2004.

77 R. Ban, M. Liu, Y. Qin, H. Wang and D. Cui, Trans. Tianjin Univ., 2012, 18, 320-329.

78 L. Ahsan, M. S. Jahan, H. Liu and Y. Ni, Bioresour. Technol., 2012, 2, 38-43.

79 A. A. Garcia and C. J. King, Ind. Eng. Chem. Res., 1989, 28, 204-212.

80 J. Ecker, T. Raab and M. Harasek, J. Membr. Sci., 2012, 389, 389-398.

81 S. Sahin, S. S. Bayazit, M. Bilgin and İ. Inci, J. Chem. Eng. Data, 2010, 55, 1519-1522.

82 K. Chawong and P. Rattanaphanee, World Acad. Sci. Eng. Technol., 2011, 80, 239-242.

83 K. Tonova, I. Svinyarov and M. G. Bogdanov, Sep. Purif. Technol., 2014, 125, 239-246.

84 M. Boonmee, O. Cotano, S. Amnuaypanich and N. Grisadanurak, Arabian J. Sci. Eng., 2016, 41, 2067-2075.

85 D. Pleissner, R. Schneider, J. Venus and T. Koch, J. Chem. Technol. Biotechnol., 2017, 92, 504-511. 
86 M. D. Waghmare, K. L. Wasewar, S. S. Sonawane and D. Z. Shende, Ind. Eng. Chem. Res., 2011, 50, 13526-13537.

87 C. Q. Ma, J. C. Li, J. H. Qiu, M. Wang and P. Xu, Appl. Microbiol. Biotechnol., 2006, 70, 308-314.

88 M. E. Marti and T. Gurkan, Sep. Purif. Technol., 2015, 156, 148-157.

89 Y. S. Huh, Y. S. Jun, Y. K. Hong, H. Song, S. Y. Lee and W. H. Hong, Process Biochem., 2006, 41, 1461-1465.

90 H. Song, Y. S. Huh, S. Y. Lee, W. H. Hong and Y. K. Hong, J. Biotechnol., 2007, 132, 445-452.

91 E. Z. Lee, Y. S. Huh, Y. S. Jun, H. J. Won, Y. K. Hong and W. H. Hong, Biotechnol. Bioprocess Eng., 2008, 13, 342-346.

92 A. Versari, M. Castellari, U. Spinabelli and S. Galassi, J. Chem. Technol. Biotechnol., 2001, 76, 485-488.

93 K. N. Kontogiannopoulos, S. I. Patsios and A. J. Karabelas, Sep. Purif. Technol., 2016, 165, 32-41.

94 Q. Wang, G. Cheng, X. Sun and B. Jin, Process Biochem., 2006, 41, 152-158.

95 Y. H. Cho, H. D. Lee and H. B. Park, Ind. Eng. Chem. Res., 2012, 51, 10207-10219.

96 C. Huang and T. Xu, Environ. Sci. Technol., 2006, 40, 52335243.

97 J. H. Choi, S. H. Kim and S. H. Moon, Sep. Purif. Technol., 2002, 28, 69-79.

98 V. A. Shaposhnik and K. Kesore, J. Membr. Sci., 1997, 136, 35-39.

99 P. J. Moon, S. J. Parulekar and S. P. Tsai, J. Membr. Sci., 1998, 141, 75-89.

100 T. Xu and C. Huang, AIChE J., 2008, 54, 3147-3159.

101 Y. Mei and C. Y. Tang, Desalination, 2018, 425, 156-174.

102 L. Bazinet, Crit. Rev. Food Sci. Nutr., 2005, 45, 307-326.

103 L. Alvarado and A. Chen, Electrochim. Acta, 2014, 132, 583597.

104 J. Mulder, Basic principles of membrane technology, Springer Science \& Business Media, 2012.

105 M. Moresi and F. Sappino, J. Food Eng., 1998, 35, 75-90.

106 N. Boniardi, R. Rota, G. Nano and B. Mazza, J. Appl. Electrochem., 1997, 27, 125-133.

107 K. Zhang, M. Wang and C. Gao, J. Membr. Sci., 2011, 366, 266-271.

108 Y. Wei, Y. Wang, X. Zhang and T. Xu, Sep. Purif. Technol., 2013, 118, 1-5.

109 S. Cattoir, D. Smets and A. Rahier, Desalination, 1999, 121, 123-130.

110 E. Güler Akgemci, M. Ersöz and T. Atalay, Sep. Sci. Technol., 2005, 39, 165-184.

111 G. S. Luo and F. Y. Wu, Sep. Sci. Technol., 2000, 35, 24852496.

112 S. S. Yi, Y. C. Lu and G. S. Luo, Sep. Purif. Technol., 2008, 60, 308-314.

113 S. Koter, Sep. Purif. Technol., 2008, 60, 251-258.

114 M. Kumar, B. P. Tripathi and V. K. Shahi, Ind. Eng. Chem. Res., 2009, 48, 923-930.

115 M. Kumar, B. P. Tripathi and V. K. Shahi, Electrochim. Acta, 2009, 54, 4880-4887.

116 P. Boyaval, J. Seta and C. Gavach, Enzyme Microb. Technol., 1993, 15, 683-686.
117 G. S. Luo, X. Y. Shan, X. Qi and Y. C. Lu, Sep. Purif. Technol., 2004, 38, 265-271.

118 S. S. Yi, Y. C. Lu and G. S. Luo, J. Membr. Sci., 2005, 255, 5765.

119 F. Hanada, et al., Bipolar membrane and method for its production, US Pat. no. 5,221,455, 22 Jun. 1993.

120 Y. Wang, C. Huang and T. Xu, J. Membr. Sci., 2011, 374, 150156.

121 F. Alvarez, R. Alvarez, J. Coca, J. Sandeaux, R. Sandeaux and C. Gavach, J. Membr. Sci., 1997, 123, 61-69.

122 S. Datta, Y. J. Lin, D. J. Schell, C. S. Millard, S. F. Ahmad, M. P. Henry, P. Gillenwater, A. T. Fracaro, A. Moradia, Z. P. Gwarnicki and S. W. Snyder, Ind. Eng. Chem. Res., 2013, 52, 13777-13784.

123 P. Boontawan, S. Kanchanathawee and A. Boontawan, Biochem. Eng. J., 2011, 54, 192-199.

124 A. K. Wardani, A. N. Hakim, Khoiruddin and I. G. Wenten, Water Sci. Technol., 2017, 75, 2891-2899.

125 J. Wood, J. Gifford, J. Arba and M. Shaw, Desalination, 2010, 250, 973-976.

126 V. I. Fedorenko, Pharm. Chem. J., 2003, 37, 157-160.

127 F. Yuan, Q. Wang, P. Yang, Y. Tian and W. Cong, Sep. Purif. Technol., 2015, 153, 51-59.

128 H. Habe, N. Yamano, S. Takeda, S. Kataoka and A. Nakayama, Desalination, 2010, 253, 101-105.

129 J. Du, N. Lorenz, R. R. Beitle and J. A. Hestekin, Sep. Sci. Technol., 2012, 47, 43-51.

130 J. Vijayakumar, R. Aravindan and T. Viruthagiri, Chem. Biochem. Eng. Q., 2008, 22, 245-264.

131 S. Suwal, J. Li, A. S. Engelberth and J.-Y. Huang, Food Bioprod. Process., 2018, 109, 41-51.

132 L. Yu, Q. Guo, J. Hao and W. Jiang, Desalination, 2000, 129, 283-288.

133 O. M. K. Readi, M. Gironès, W. Wiratha and K. Nijmeijer, Ind. Eng. Chem. Res., 2013, 52, 1069-1078.

134 T. V. Eliseev, E. V. Krisilova, V. A. Shaposhnik and A. E. Bukhovets, Desalin. Water Treat., 2010, 14, 196-200.

135 X. Lin, J. Pan, M. Zhou, Y. Xu, J. Lin, J. Shen, C. Gao and B. Van der Bruggen, Ind. Eng. Chem. Res., 2016, 55, 28132820.

136 R. Nikbakht, M. Sadrzadeh and T. Mohammadi, J. Food Eng., 2007, 83, 596-604.

137 B. Iglinski, S. Koter, R. Buczkowski and M. Lis, Pol. J. Environ. Stud., 2006, 15, 411-417.

138 X. Sun, H. Lu and J. Wang, J. Cleaner Prod., 2017, 143, 250256.

139 K. Prochaska and M. J. Woźniak Budych, J. Membr. Sci., 2014, 469, 428-435.

140 H. Habe, Y. Shimada, T. Fukuoka, D. Kitamoto, M. Itagaki, K. Watanabe, H. Yanagishita and K. Sakaki, J. Biosci. Bioeng., 2010, 110, 690-695.

141 V. Habova, K. Melzoch, M. Rychtera, L. Pribyl and V. Mejta, Czech J. Food Sci., 2001, 19, 73-80.

142 V. Habova, K. Melzoch, M. Rychtera and B. Sekavova, Desalination, 2004, 162, 361-372.

143 H. W. Ryu, Y. M. Kim and Y. J. Wee, Biotechnol. Bioprocess Eng., 2012, 17, 1261-1269. 
144 G. Q. Chen, F. I. I. Eschbach, M. Weeks, S. L. Gras and S. E. Kentish, Sep. Purif. Technol., 2016, 158, 230-237.

145 M. L. Lameloise and R. Lewandowski, J. Membr. Sci., 2012, 403-404, 196-202.

146 X. Liu, Q. Li, C. Jiang, X. Lin and T. Xu, J. Membr. Sci., 2015, 482, 76-82.

147 D. A. Glassner, P. Elankovan, D. R. Beacom and K. A. Berglund, Appl. Biochem. Biotechnol., 1995, 51, 73-82.

148 P. A. Sosa, C. Roca and S. Velizarov, J. Membr. Sci., 2016, 501, 236-247.

149 L. Fu, X. Gao, Y. Yang, F. Aiyong, H. Hao and C. Gao, Sep. Purif. Technol., 2014, 127, 212-218.

150 M. Szczygiełda, J. Antczak and K. Prochaska, Sep. Purif. Technol., 2017, 181, 53-59.

151 K. Prochaska, J. Antczak, M. Regel-Rosocka and M. Szczygiełda, Sep. Purif. Technol., 2018, 192, 360-368.

152 L. J. Andrés, F. A. Riera and R. Alvarez, J. Chem. Technol. Biotechnol., 1997, 70, 247-252.

153 R. Datta, Recovery and purification of lactate salts from whole fermentation broth by electrodialysis, US Pat. no. 4,885,247, 5 Dec. 1989.

154 M. Bailly, Desalination, 2002, 144, 157-162.

155 K. N. Mani, J. Membr. Sci., 1991, 58, 117-138.

156 M. B. Arora, J. A. Hestekin, S. W. Snyder, E. J. St. Martin, Y. J. Lin, M. I. Donnelly and C. S. Millard, Sep. Sci. Technol., 2007, 42, 2519-2538.

157 T. Ho, A. Kurup, T. Davis and J. Hestekin, Sep. Sci. Technol., 2010, 45, 433-446.

158 A. M. Lopez and J. A. Hestekin, J. Membr. Sci., 2015, 493, 200-205.

159 Y. J. Lin, et al., Single-stage separation and esterification of cation salt carboxylates using electrodeionization, US Pat. no. 7,141,154, 28 Nov. 2006.

160 Y. J. Lin, et al., Carbon dioxide capture using resin-wafer electrodeionization, US Pat. no. 8,506,784, 13 Aug. 2013.

161 A. M. Lopez and J. A. Hestekin, Sep. Purif. Technol., 2013, 116, 162-169.

162 G. J. Lye and J. M. Woodley, Trends Biotechnol., 1999, 17, 395-402.

163 G. Min tian, M. Hirata, M. Koide, H. Takanashi and T. Hano, Process Biochem., 2004, 39, 1903-1907.

164 M. Hirata, M. t. Gao, E. Toorisaka, H. Takanashi and T. Hano, Biochem. Eng. J., 2005, 25, 159-163.

165 H. Danner, L. Madzingaidzo, C. Thomasser, M. Neureiter and R. Braun, Appl. Microbiol. Biotechnol., 2002, 59, 160169.

166 M. Kumar, B. P. Tripathi and V. K. Shahi, J. Chem. Technol. Biotechnol., 2010, 85, 648-657.

167 G. Liu, H. Luo, H. Wang, B. Wang, R. Zhang and S. Chen, J. Membr. Sci., 2014, 471, 179-184.

168 X. Wang, Y. Wang, X. Zhang and T. Xu, Bioresour. Technol., 2012, 125, 165-171.
169 X. Wang, Y. Wang, X. Zhang, H. Feng and T. Xu, Bioresour. Technol., 2013, 147, 442-448.

170 H. Luo, X. Cheng, G. Liu, Y. Zhou, Y. Lu, R. Zhang, X. Li and W. Teng, J. Membr. Sci., 2017, 523, 122-128.

171 Y. Lu, H. Luo, K. Yang, G. Liu, R. Zhang, X. Li and B. Ye, Bioresour. Technol., 2017, 243, 118-125.

172 X. Zhu, M. C. Hatzell, R. D. Cusick and B. E. Logan, Electrochem. Commun., 2013, 31, 52-55.

173 H. Danner, L. Madzingaidzo, M. Holzer, L. Mayrhuber and R. Braun, Bioresour. Technol., 2000, 75, 181-187.

174 L. Madzingaidzo, H. Danner and R. Braun, J. Biotechnol., 2002, 96, 223-239.

175 C. Fargues, B. Broyart, M. Benmami and M. L. Lameloise, Sep. Sci. Technol., 2006, 41, 359-377.

176 M. Bailly, H. Roux de Balmann, P. Aimar, F. Lutin and M. Cheryan, J. Membr. Sci., 2001, 191, 129-142.

177 P. Boyaval, C. Corre and S. Terre, Biotechnol. Lett., 1987, 9, 207-212.

178 B. Norddahl, Fermentative production and isolation of lactic acid, US Pat. no. 6,319,382, 20 Nov. 2001.

179 B. Norddahl, S. Eriksen and F. Pedersen, Method for producing lactic acid, US Pat. application no. 10/297,090, 2004.

180 S. Tejayadi and M. Cheryan, Appl. Biochem. Biotechnol., 1988, 19, 61-70.

181 S. Pappa, Direction in food science and technology and human nutrition, MSc thesis, Agricultural University of Athens, 2017.

182 S. Hong and M. Elimelech, J. Membr. Sci., 1997, 132, 159181.

183 A. W. Zularisam, A. F. Ismail and R. Salim, Desalination, 2006, 194, 211-231.

184 H. Choi, K. Zhang, D. D. Dionysiou, D. B. Oerther and G. A. Sorial, Sep. Purif. Technol., 2005, 45, 68-78.

185 A. R. Costa, M. N. de Pinho and M. Elimelech, J. Membr. Sci., 2006, 281, 716-725.

186 J. R. Du, S. Peldszus, P. M. Huck and X. Feng, Water Res., 2009, 43, 4559-4568.

187 S. Mikhaylin and L. Bazinet, Adv. Colloid Interface Sci., 2016, 229, 34-56.

188 A. H. Braghetta, Master thesis, University of North Carolina, 1995.

189 Y.-F. Yang, L.-S. Wan and Z.-K. Xu, J. Adhes. Sci. Technol., 2011, 25, 245-260.

190 V. M. Kochkodan and V. K. Sharma, J. Environ. Sci. Health, Part A: Toxic/Hazard. Subst. Environ. Eng., 2012, 47, 17131727.

191 J. Drelich, E. Chibowski, D. D. Meng and K. Terpilowski, Soft Matter, 2011, 7(21), 9804-9828.

192 N. F. Himma, S. Anisah, N. Prasetya and I. G. Wenten, J. Polym. Eng., 2016, 36, 329-362.

193 D. Ariono and A. K. Wardani, IOP Conf. Ser.: Mater. Sci. Eng., 2017, 214, 012014. 